\title{
"Unutarnja" kriza pravosuđa? Stavovi pripadnika pravničkih profesija o pravosuđu u Hrvatskoj i Srbiji
}

\author{
MARKO MRAKOVČIĆ \\ Pravni fakultet, Sveučilište u Rijeci \\ DANILO VUKOVIĆ \\ Pravni fakultet, Univerzitet u Beogradu
}

\begin{abstract}
Sažetak
$\mathrm{U}$ radu se analizira koliko pripadnici različitih pravničkih profesija $\mathrm{u} \mathrm{Hr}-$ vatskoj i Srbiji imaju povjerenja u institucije pravosudnih sustava i koliko su zadovoljni funkcioniranjem njihovih važnih dijelova. U prvom dijelu rada predstavljaju se argumenti kulturalističkog i institucionalnog pristupa u objašnjenju temelja povjerenja u institucije, određuju se karakteristike "dobrog" pravosuđa u kontekstu koncepta demokratske vladavine prava i daje se društveni kontekst provedbe pravosudnih reformi u obje zemlje u posljednjih dvadesetak godina. U drugom, empirijskom dijelu rada daje se prikaz rezultata analize podataka prikupljenih online anketnim istraživanjem provedenim 2018. godine u Hrvatskoj i Srbiji. Rezultati u obje zemlje pokazuju i nisku razinu povjerenja u institucije pravosudnog sustava i duboko nezadovoljstvo općim stanjem u pravosuđu i funkcioniranjem njegovih važnih dijelova. Pokazujući povezanost između (ne)povjerenja u institucije i (ne)zadovoljstva njihovim radom, analiza ide u prilog pretpostavkama institucionalne perspektive. Zaključujemo da dobiveni rezultati ukazuju na "unutarnju" krizu povjerenja u pravosuđu u obje zemlje koja prati evidentnu "izvanjsku" krizu srpskog pravosuđa i latentne napetosti u i oko hrvatskog pravosuđa.
\end{abstract}

Ključne riječi: pravosuđe, kriza, legitimitet, povjerenje u institucije, pravničke profesije, Hrvatska, Srbija

\section{Uvod}

Povjerenje građana $\mathrm{u}$ institucije je preduvjet funkcioniranja i legitimnosti demokratskog poretka i oko toga postoji suglasnost u suvremenoj političkoj i socijalnoj teoriji (Inglehart, 1997; Hetherington, 1998; Maldini, 2008; Matić, 2000). Istraži- 
vanja provedena u Srbiji i Hrvatskoj često ukazuju na svojevrsnu krizu povjerenja u sustav i pojedine njegove institucije (Baloban i Rimac, 1998; Mrakovčić, 2010; Sekulić i Šporer, 2010; Gvozdanović, 2014; CESID, 2017; usp. podatke Eurobarometra za Hrvatsku i European Value Survey za Srbiju). Pravosuđe je često jedan od "dežurnih krivaca" jer je, kao što ćemo vidjeti, pod udarom vlasti koje teže ograničiti njegovu neovisnost i sposobnost da kontrolira korupciju i krađu javnih resursa. Otuda njegov legitimitet opada, i u tom pogledu malo se što novo može reći (cf. CESID, 2017; Bešić, 2016). Zato se u ovom tekstu nećemo baviti općom percepcijom pravosuđa, već nudimo jednu drugu, "unutarnju” perspektivu na rad i legitimnost pravosuđa. Prikazat ćemo stavove pravnika o povjerenju u institucije, sudaca, državnih odvjetnika, odvjetnika, pravnih znanstvenika i pravnika koji rade izvan pravosuđa (u privredi i upravi), kao i podatke o njihovom zadovoljstvu stanjem u pravosuđu i njegovim važnim aspektima. Naš argument je da pravosudni sustavi u ove dvije zemlje nisu samo u "izvanjskoj” krizi koja je obilježena njihovom neefikasnošću i malom sposobnošću da se odupru političkoj kontroli vladajućih elita, već da je na djelu jedna manje vidljiva, "unutarnja" kriza pravosuđa. Ta kriza ogleda se najprije u dubokom nezadovoljstvu radom pravosudnih sustava, a potom i u odsustvu povjerenja u te institucije. Odsustvo povjerenja zapravo je odsustvo legitimiteta, jedne od ključnih karakteristika za funkcioniranje pravosuđa. Riječ je o unutarnjem legitimitetu koji izvire iz povjerenja u sustav upravo onih aktera na kojima taj sustav počiva, pravnika. Shodno tome, teško je zamisliti da će tako temeljno podriveni pravosudni sustavi biti u stanju efikasno obavljati one funkcije koje se od njih očekuju u suvremenim demokracijama, funkcije čuvara interesa i prava građana i pravnog poretka.

Rad se sastoji od nekoliko dijelova. U prva tri odjeljka prikazan je teorijskokonceptualni okvir rada, razmotren je društveni kontekst provedbe pravosudnih reformi u Hrvatskoj i Srbiji te postavljene hipoteze, uzorak istraživanja i korišteni mjerni instrumenti. U sljedeća tri odjeljka analiziramo razinu povjerenja u institucije i razinu zadovoljstva pravnika funkcioniranjem pravosuđa i njegovih važnih dijelova. Uz to, analiziramo u kojoj mjeri razina zadovoljstva funkcioniranjem pravosudnog sustava utječe na razinu povjerenja koje ispitanici imaju spram njihovih institucija. Na kraju slijede zaključna razmatranja. ${ }^{1}$

${ }^{1}$ Ovaj rad nastao je na osnovi samostalnog istraživanja "Pravnici i pravnička profesija u Srbiji i Hrvatskoj" koje su autori proveli tijekom 2018. godine u Hrvatskoj i Srbiji. Naknadno je istraživanje prošireno i na Bosnu i Hercegovinu. Preliminarni rezultati istraživanja predstavljeni su u Vuković, Mrakovčić i Forić (2018). 


\section{Teorijsko-konceptualna polazišta}

Postoje dvije škole mišljenja u vezi s povjerenjem u institucije: kulturalistička i institucionalna. U kulturalističkoj tradiciji daju se tri glavna argumenta u prilog tezi da je povjerenje preduvjet za funkcionalnu demokraciju. Po prvom ono povećava podršku demokratskom režimu, po drugom omogućava da javnost prihvaća demokratske vrijednosti i ideale, a odbacuje nedemokratske alternative, i po trećem povećava i kvantitetu i kvalitetu političke participacije. U toj teorijskoj perspektivi povjerenje $u$ institucije je egzogeno i dolazi izvan političke sfere. Ono, naime, proizlazi iz stavova o ljudima koji su duboko usađeni u kulturne norme i vjerovanja koji se prenose u ranim razdobljima socijalizacije. Prema tom shvaćanju, interpersonalno povjerenje, koje usvajamo tijekom djetinjstva, pretvara se u povjerenje $\mathrm{u}$ institucije, tako da postoji hijerarhija povjerenja od nama bliskih ljudi preko generalnog interpersonalnog povjerenja do povjerenja u institucije (Mishler i Rose, 2001: 31; 2005: 1052-1053; Levi i Stoker, 2000).

$\mathrm{U}$ institucionalnoj perspektivi povjerenje $\mathrm{u}$ institucije je endogeno i povezano je s funkcioniranjem institucija. To je racionalni stav građana kojim se evaluira rad institucija. One institucije koje dobro rade generiraju i veće povjerenje, a one koje ne rade dobro izazivaju nepovjerenje i skepticizam. Različiti teoretičari naglašavaju da izvori te procjene mogu biti ekonomski efekti institucija, ali i zaštita sloboda, smanjenje korupcije ili uspostavljanje vladavine prava (Mishler i Rose, 2005: 1054). Prema nekim autorima, postoji veza između rada institucija i ne samo povjerenja u institucije već i interpersonalnog povjerenja, te nedostatak generaliziranog povjerenja u društvu proizlazi iz lošeg rada institucija, na primjer onih koje izazivaju korupciju u društvu (Newton i Norris, 1999). Suprotno tome, institucije koje nisu korumpirane, institucije koje omogućavaju redistribuciju društvenog bogatstva i one u kojima su različiti politički interesi i društvene grupe proporcionalno zastupljeni proizvode veću razinu generaliziranog socijalnog povjerenja (Freitag i Bühlmann, 2009).

U oba teorijska pravca postoje makro- i mikropristupi. Makrokulturne teorije naglašavaju homogenizirajuće tendencije nacionalnih tradicija i ne ostavljaju puno prostora za varijacije u povjerenju među pojedincima. Nasuprot tome, mikrokulturne teorije usmjerene su na razlike $\mathrm{u}$ individualnim iskustvima socijalizacije koje vide kao izvor značajnih varijacija u političkom povjerenju unutar društava i između njih. Još je veća razlika između makro- i mikroinstitucionalnih teorija. Makroinstitucionalne teorije naglašavaju rad i rezultate institucija u područjima kao što su ekonomski rast, efikasno upravljanje i izbjegavanje korupcije te pretpostavljaju da rezultati rada institucija direktno utječu na stavove ljudi. Nasuprot tome, mikroinstitucionalne teorije naglašavaju da su individualne procjene učinka institucija uvjetovane individualnim preferencijama i iskustvima. One ovise od toga što neka osoba procjenjuje 
da je važnije, politički integritet ili ekonomski rast, i o tome je li iskusila negativne efekte korupcije ili koristi od ekonomskog rasta (Mishler i Rose, 2001: 31).

Prethodno pokazuje zašto je povjerenje u političke institucije važno. Ali, zašto proučavamo povjerenje u pravosuđe? Prvi razlog leži u ulozi pravosuđa: sudovi donose važne odluke; nekada su te odluke pitanje života i smrti za neke ili brojne ljude, nekada se odnose na budućnost političke zajednice (na primjer, u slučaju konačne ocjene predsjedničkih izbora u SAD 2001. godine od strane Vrhovnog suda; Chemerinsky, 2001; Gibson, Caldeira i Spence, 2003) ili na budućnost institucija koje su konstitutivne za samo društvo (na primjer, slučaj s odlukama Ustavnog suda u kontekstu legalizacije istospolnih brakova u Južnoafričkoj Republici 2005. godine; Roux, 2009; De Vos i Barnard, 2007). Mnoge od tih odluka su kontroverzne i tiču se moralnih i političkih pitanja o kojima često nema suglasnosti u društvu. Građani te odluke prihvaćaju onda kada sudovi uživaju legitimitet. ${ }^{2}$ Budući da građani ne biraju suce i da suci nisu izravno odgovorni građanima (engl. accountable), legitimnost sudova se razlikuje od legitimnosti druge dvije grane vlasti. Sudovi uživaju legitimitet jer građani imaju povjerenja u njih. Legitimnost proistječe iz sposobnosti pravosuđa da donosi nepristrane odluke i da poštuje princip proceduralne pravičnosti. Poštovanje tog principa najjasnije se pokazuje na jednom test-ishodu: da sud presudi u korist onih koji nemaju društvenu moć ili, još važnije, da osudi one koji je imaju (Bühlmann i Kunz, 2011: 317-318). Preduvjet za to jest neovisnost pravosuđa, odnosno njegova sposobnost da se odupre političkim pritiscima. Sudska neovisnost ima više dimenzija: mogućnost donošenja odluka na koje politički interesi nemaju utjecaj, autonomija u odnosu na izvršnu i zakonodavnu vlast, financijska neovisnost pravosuđa u odnosu na izvršnu vlast te količina ovlasti koje sudstvo ima (ibid.: 322-323). Neovisnost pravosuđa te povjerenje u sudove i legitimnost koja iz njega izvire važni su jer omogućavaju da sudska vlast kontrolira druge dvije grane vlasti. U tom smislu se povjerenje u pravosuđe dovodi u vezu s temeljnim pretpostavkama vladavine prava i demokracije.

Kada je riječ o izvršnoj vlasti, rezultati njenog rada mogu se procjenjivati na osnovi različitih kriterija: dobrih ekonomskih rezultata, efekata borbe protiv korupcije, njegovanja duha demokracije i tolerancije itd. Slično tome, i pravosuđe može biti dobro ako je pravedno, efikasno, dostupno, neovisno itd. No, koje su točno odlike dobrog pravosuđa? Da bismo dobili neproizvoljnu i teorijski utemeljenu listu karakteristika dobrog pravosuđa, počeli smo od koncepta demokratske vladavine

2 Pod legitimitetom institucije ili odluke u čvrsto sociološkom smislu podrazumijevamo to da relevantna javnost prihvaća tu instituciju ili odluku kao opravdanu, prikladnu, ili da joj na neki drugi način daje podršku iz razloga koji se ne tiču samo straha od sankcija ili osobne dobiti. S druge strane, legitimitet u mekom smislu podrazumijeva da se odluke prihvaćaju jednostavno iz navike ili interesa (Fallon, 2005: 1795-1796). 
prava kao poželjnog oblika uređenja društva. Brian Tamanaha ističe da tri ideje prožimaju sve rasprave o vladavini prava. Prva ideja se odnosi na to da je "vlada ograničena zakonom". Vlada je ograničena zakonom u dva smisla: vlast se mora podrediti važećim zakonima, a ako ih želi mijenjati, to ne može napraviti proizvoljno, jer je ograničena idejama prirodnog ili božanskog prava (ranije) ili ljudskih ili građanskih prava (danas) (Tamanaha, 2004: 115). Podjela vlasti i neovisno sudstvo nužan su preduvjet za prvo ograničenje (ibid.: 117). Druga ideja odnosi se na neke osobine zakona. Zakoni moraju biti opći, jednako primjenjivi na sve ljude i moraju dovesti do predvidljivosti u ljudskom ponašanju. U najširem proceduralnom smislu formalna legalnost uključuje i to da u sudskom procesu postoji mogućnost pravičnog suđenja (ibid.: 119). Treća ideja odnosi se na vladavinu zakona, a ne ljudi. Kako se zakoni ne mogu sami tumačiti ili primjenjivati, potrebni su ljudi, obučeni i s posebnim moralnim kvalifikacijama, takvi da budu predstavnici svoje zajednice, ali i neovisni od drugih grana vlasti (ibid.: 123-125). Da bi se uspostavilo neovisno sudstvo, potrebno je da se suci biraju na osnovi stručnih osobina, da imaju dug mandat, da imaju odgovarajući materijalni status, da budu zaštićeni od proizvoljnih smjena te da sam sustav ima dovoljno financijskih i drugih sredstava za funkcioniranje (osoblje, sudnice i sl.) (ibid.: 124).

Dakle, da bi demokratska vladavina prava bila uspostavljena, pravosuđe treba posjedovati određene osobine. Prva među tim osobinama je neovisnost od drugih grana vlasti. Neovisnost podrazumijeva da je pravosuđe sposobno oduprijeti se pritisku vlasti da donosi odluke u njenom interesu te da tu neovisnost čuva na nivou institucija i zakona (de iure neovisnost) i na nivou praksi i neposrednog iskustva zaposlenih (de facto neovisnost). Druga osobina je stručnost, odnosno sposobnost pravosuđa da tumači zakone i donosi argumentirane odluke, a osnovna pretpostavka za to je da suci i državni odvjetnici, kao i ostali zaposlenici na sudovima i u državnim odvjetništvima, imaju stručne kapacitete. Treća osobina je efikasnost, odnosno sposobnost pravosuđa da donosi odluke u razumnom roku, bez nepotrebnog odlaganja. Efikasnost je odabrana kao indikator i zato što su pravosuđa obje zemlje bila kritizirana zbog neefikasnosti i velikog broja neriješenih slučajeva, što je bio jedan od pokretača reformi (Dallara, 2014; MPV, 2014). Upravo te osobine pravosuđa koje zahtijeva vladavina prava uzeli smo kao pokazatelje dobrog pravosudnog sustava $i$ istraživanjem smo mjerili zadovoljstvo pravnika radom pravosuđa po tim dimenzijama, polazeći od hipoteze da će nezadovoljstvo radom pravosuđa rezultirati i manjim povjerenjem pravnika u njega, i obrnuto. ${ }^{3}$

3 Četvrti pokazatelj kvalitete pravosuđa je njegova dostupnost. Pod dostupnošću podrazumijevamo to da svi ljudi, nezavisno od svojih socioekonomskih karakteristika, mogu koristiti pravosuđe i ostvariti pred njim svoja prava. U tom smislu dostupnost se može promatrati kao jedna dimenzija općenitosti zakona, njegove jednake primjenljivosti na sve ljude. Ipak, taj aspekt nije uvršten u ovaj rad zbog složenosti analize, te će biti predmet naše buduće analize. 
Pored navedenog, $\mathrm{u}$ istraživanju smo krenuli od teorijsko-konceptualne pretpostavke da pred sobom imamo ne jednu, nego više pravničkih profesija (Shultz i Shaw, 2003) - suce, državne odvjetnike, odvjetnike i javne bilježnike, da navedemo samo najvažnije - koje se nekada nazivaju pravosudnim profesijama (Spasić et al., 2011; Sibinović, 2011). Krenuli smo od pretpostavke da se riječ "pravnik" referira na osobu s pravničkim obrazovanjem (koja je tim obrazovanjem stekla kvalifikacije da se bavi određenim zanimanjem) te da biti pravnik ne znači imati jedinstven profesionalni identitet. Odnosno, pretpostavili smo da se profesionalni identiteti pravnika značajno oblikuju tek nakon završenog formalnog obrazovanja, kroz pravničku praksu unutar sudova, državnog odvjetništva, odvjetništva ili drugih profesija izvan pravosuđa (Vuković, Dabetić i Forić, 2019). Stoga očekujemo da će (1) specifične institucionalne strukture povezane s pravosudnim sustavom i (2) profesionalne prakse koje u njima vladaju značajno oblikovati i specifičnosti profesionalnih identiteta pojedinih grupa profesija i specifičnosti njihovih stavova o funkcioniranju pravosuđa. Iz tog razloga u centru naše pažnje nalaze se suci, državni odvjetnici, odvjetnici, pravni znanstvenici s pravnih fakulteta i pravnici u privredi i javnoj upravi. Prve tri navedene profesije izabrane su jer su konstitutivni element pravosudnog sustava, pravni znanstvenici s pravnih fakulteta izabrani su jer ga reproduciraju i svojim znanstveno-nastavnim radom i svojim stavovima koji imaju ulogu u njegovom oblikovanju, a pravnici izvan pravosuđa izabrani su jer su u interakciji sa sustavom, pa smo smatrali da ga mogu ocjenjivati kao relativno neovisni akteri.

\section{Društveni kontekst provedbe pravosudnih reformi}

U razdoblju neposredno nakon stjecanja državne neovisnosti i rata hrvatsko pravosuđe bilo je neovisno samo "na papiru". Principi neovisnosti, trajnog imenovanja i podjele vlasti nisu se primjenjivali u praksi, a političke stranke i mreže nepotizma imale su jak utjecaj na postavljanje i napredovanje sudaca (Uzelac, 2013: 199-200). Nezadovoljavajuće stanje u pravosuđu dovelo je do odljeva brojnih kadrova u druge pravničke profesije. To se negativno odrazilo na profesionalne kapacitete hrvatskog pravosuđa (Dallara, 2014: 45). Međutim, nakon 2000. godine stanje u pravosuđu se počelo popravljati. Mnogi autori smatraju da je proces približavanja EU dao ključni poticaj za reforme pravosuđa u Hrvatskoj (Noutcheva i Aydin-Düzgit, 2012; Cerruti, 2014; Dallara, 2014: 48). U tom su smislu posebno značajna bila dva procesa. Prvo, ustavnim amandmanima iz lipnja 2010. godine povećana je autonomija Državnog sudbenog vijeća (DSV) i Državnoodvjetničkog vijeća (DOV) te je smanjen utjecaj izvršne vlasti na proces imenovanja sudaca i državnih odvjetnika. Većinu članova oba tijela sada na izborima biraju suci, odnosno državni odvjetnici. Drugo, u razdoblju između 2005. i 2010. godine smanjen je broj zaostalih slučajeva s 1,6 na 0,8 milijuna, a došlo je i do racionalizacije mreže sudova i državnih odvjetništava, odnosno do smanjenja broja općinskih sudova i državnih odvjetništava, kao i pre- 
kršajnih, županijskih i trgovačkih sudova (HS, 2010: 13). Taj proces smanjivanja broja sudova i državnih odvjetništava nastavljen je i nakon pridruživanja EU (HS, 2012: 4). Dakle, u razdoblju do ulaska u EU reforme su bile usmjerene na jačanje neovisnosti i efikasnosti pravosuđa. U nadolazećem razdoblju poseban naglasak stavljen je na profesionalne kompetencije sudaca. One su značajno unaprijeđene uvođenjem Pravosudne akademije, koja je postala i kanal za ulazak u pravosuđe generalno gledano (Cerruti, 2014).

Važan pomak u razvoju pravne države predstavljalo je uhićenje nekadašnjeg premijera Sanadera pod optužbama za korupciju krajem 2010. godine i raskid s dotadašnjom politikom za koju se vjerovalo da je bila tolerantna prema različitim oblicima korupcije (Noutcheva i Aydin-Düzgit, 2012: 66). Uspostavljanje Ureda za suzbijanje korupcije i organiziranog kriminala (USKOK) predstavljalo je posebnu prekretnicu. USKOK je u razdoblju prije pristupanja EU vodio značajne istrage u vezi s privatizacijom, korupcijom među sveučilišnim profesorima, u vezi s dodjeljivanjem statusa ratnog vojnog invalida te zloupotrebama vlasti na najvišoj razini (Elbasani i Šabić, 2018: 14). Uspostavljeni su i posebni odjeli županijskih sudova u Osijeku, Rijeci, Splitu i Zagrebu za korupciju i organizirani kriminal (HS, 2013: 3).

Iako su te "promjene prvog reda" unaprijedile neovisnost i efikasnost sudstva, postoje autori koji su kritični ili skeptični u pogledu njihovih dometa (Dallara, 2014: 49). Tome posebno doprinose negativna iskustva Rumunjske i Bugarske (Coman, 2014). Posredno to dokazuju i rezultati evaluacije kvalitete rada pravosudnog sustava u Hrvatskoj (IPSOS, 2016). Velik postotak građana Hrvatske ne vjeruje sudovima (59\%) i državnom odvjetništvu (54\%). To je samo dio relativno niskog povjerenja u institucije: $69 \%$ nema povjerenja u vladu, 55\% u nevladine organizacije, dok je povjerenje u vojsku i policiju visoko (samo $7 \%$ građana ne vjeruje vojsci, a $26 \%$ policiji). Građani nemaju povjerenja ni u sposobnost pravosuđa da poštuje proceduralnu pravdu - polovina ispitanika smatra da prosječan građanin ne može očekivati pošteno suđenje. I dok je 2010. godine još i postojao određeni stupanj optimizma u pogledu promjena ( $44 \%$ ispitanika je smatralo da se pravosuđe mijenja na bolje), 2016. godine dominira pesimizam (samo $27 \%$ ispitanika vidi promjenu na bolje), kao i osjećaj da se stvari ne mijenjaju. Najvažniji problemi u pravosuđu su trajanje postupka ( $75 \%$ ispitanika smatra da je to velik i najveći problem), utjecaj politike na sudove i državno odvjetništvo $(66 \%)$, pa onda troškovi postupka (63\%), utjecaj politike na policiju (57\%), procedure (57\%), dostupnost i jasnoća zakona (55\%), korupcija među sucima (51\%) itd. Zaposleni na sudovima probleme uglavnom vide u eksternim faktorima kao što su zakoni koji se često mijenjaju ili su nedorečeni (82\% i 80\%), utjecaj politike na sudove i policiju (73\%), sklonost parničenju (72\%), korupcija u policiji (71\%) itd. Kao i građani, oni mogućnost korupcije vide u dugotrajnosti postupaka, načinu izvještavanja medija te mogućnosti političkog utjecaja. 
Neke od tih procesa i društvenih faktora nalazimo i u Srbiji. Za početak, srpsko pravosuđe radi u društvenom i političkom kontekstu koji je obilježen mrežama klijentelizma i korupcije, ali i kontekstu vrlo raširene podrške vrijednostima pravne države u općoj populaciji (Cvejić, ur., 2016; Vuković, 2018; Vuković i Cvejić, 2019 ; 2014). Reforme u srpskom pravosuđu provode se različitim intenzitetom već gotovo dva desetljeća. Vjerojatno je najupečatljivija bila ona provedena u razdoblju između 2006. i 2012. godine. Ona je bila inspirirana idejom da se pravosuđe reformira u sklopu priprema za integraciju u EU i podržali su je brojni međunarodni akteri (Dallara, 2014: 95). Tom reformom unaprijeđena je IT struktura sudstva, a došlo je i do racionalizacije mreže sudova. ${ }^{4}$ Također je došlo do odgovarajuće organizacijske promjene u strukturi državnog odvjetništva. Najkontroverzniji aspekt reforme bio je opći reizbor sudaca i državnih odvjetnika koji je doveo do otpuštanja 837 sudaca i preko 200 državnih odvjetnika i zamjenika državnih odvjetnika. Taj poduhvat bio je predmet oštrih stručnih i političkih kritika i u Srbiji i iz EU. Jedan od osnovnih prigovora bio je da je reformom narušen princip doživotnog imenovanja sudaca koji je zaštićen Ustavom i zakonima, te se reizbor sudaca u pravilu ocjenjivao kao neustavan (Marković, 2010; Marinković, 2009; Orlović, 2010; Rakić-Vodinelić, 2010; Rakić-Vodinelić et al., 2012). Tom procesu prigovara se i da Visoki savet sudstva i Državno veće tužilaca nisu radili u punim sastavima, da žalbe odbijenih kandidata nisu obrađivane, da kandidati koji su se prvi put prijavili nisu intervjuirani (EC, 2010: 10), da je proces izbora bio netransparentan (Pavlović, 2010: 91) te da donesene odluke nisu bile individualizirane (Marković, 2010). Generalno gledano, čini se da je vlast iskoristila organizacijske reforme ne samo da unaprijedi stručne kapacitete sudstva već i da se riješi neposlušnih sudaca (Mendelski, 2015: 335). Osim iz znanstvene javnosti, posebno snažan otpor dolazio je od Društva sudija Srbije i drugih aktera iz domene građanskog društva. Odlukama Ustavnog suda iz 2010. i 2012. godine neki od ključnih elemenata reforme poništeni su i naloženo je da se ponovo izaberu državni odvjetnici i suci koji nisu prošli "reizbor" (za više detalja vidi Rakić-Vodinelić et al., 2012: 221 ff; Dallara, 2014: 95 ff). I kasniji izbori bili su predmet kritika. Primjerice, EU je kritizirao izbor 55 kandidata u državnom odvjetništvu koji je proveden u jesen 2015. godine zbog toga što nije bio zasnovan na njihovim zaslugama (EU, 2016: 55).

Kada je riječ o efikasnosti, u posljednjih nekoliko godina srpsko pravosuđe bilježi određene uspjehe, ali i kritike (EC, 2018: 17 ff; raniji izvještaji Europske komisije također sadrže kritike, npr. EC, 2010; 2014). Krajem 2011. godine bilo je 3,3

${ }^{4}$ Nekadašnjih 138 općinskih sudova reorganizirano je u 34 osnovna suda, ustanovljeno je 26 viših sudova, 4 apelaciona suda i Vrhovni kasacioni sud (kasnijim zakonskim izmjenama uspostavljena je mreža sudova koju čine 25 viših sudova, 66 osnovnih sudova, 16 privrednih sudova, 44 prekršajna suda, 4 apelaciona suda i Vrhovni kasacioni sud). 
milijuna zaostalih slučajeva (EC, 2012), 2013. godine broj zaostalih slučajeva pao je na 2,8 milijuna (EC, 2014), u 2014. godini još je više smanjen, na 0,9 milijuna, a godinu kasnije narastao je na 1,1 milijun (EC, 2016: 56). Krajem 2017. godine bilo je 1,9 milijuna zaostalih slučajeva, od čega je 1,1 milijun regularnih slučajeva, a 0,8 milijuna su predmeti izvršenja. ${ }^{5}$ Tijekom čitavog tog razdoblja postavljani su i drugi prigovori sudstvu, na primjer, zbog neujednačene sudske prakse, nejednakog opterećenja sudova, pokušaja da se izbor novih sudaca ograniči na kandidate koji su pohađali Pravosudnu akademiju ${ }^{6}$ itd.

Tijekom 2017. godine započet je sljedeći krug pravosudnih reformi. Njihov cilj bila je izmjena Ustava iz 2006. godine. Iako postoji konsenzus stručne javnosti da sadašnja ustavna rešenja treba mijenjati (npr. CEPRIS, 2016; Jerinić i Kljajević, 2016), kao i kod prethodnih reformi, širi društveni i profesionalni konsenzus o tome kako bi to trebalo provesti promjene nije uspostavljen. Nakon nekoliko mjeseci "razgovora" bez jasnog prijedloga ustavnih reformi, veći dio aktera koji okupljaju pripadnike pravne profesije i pravne stručnjake povukao se iz javne rasprave. Jedan od ključnih prigovora najnovijim ustavnim reformama je da izvršna vlast i političke stranke zadržavaju kontrolu nad pravosuđem na osnovi kontrole Visokog saveta sudstva i Državnog veća tužilaca u čijem članstvu i dalje imaju većinu (Petrović Škero, 2018; Ilić, 2018). ${ }^{7}$ Vanjske procjene i dalje govore o pritiscima predstavnika izvršne vlasti na pravosuđe i odnose se na komentiranje rada pravosuđa i presuda te na otvorene napade na suce koji donose odluke koje nosiocima vlasti nisu po volji (EC, 2018: 14; R.D., 2018).

Kao i u Hrvatskoj, povjerenje javnosti u pravosuđe je nisko i u razdoblju između 2013. i 2017. godine nije prelazilo 21\%, dok je, primjera radi, u 2017. godini u EU-28 iznosilo 50\% (CESID, 2017, za Srbiju i Eurobarometar za EU). Dok je u EU povjerenje u pravosuđe veće nego u vladu (36\%) i parlament (35\%) (ali manje nego u policiju i vojsku - 72\% i 73\%), povjerenje u srpsko pravosuđe niže je nego u parlament (25\% u 2017. godini), vladu (33\%), policiju (39\%) i vojsku (57\%).

${ }^{5}$ Funkcionalna analiza pravosuđa u Srbiji koju je proveo Multidonorski poverenički fond za podršku sektoru pravosuđa u Srbiji pokazuje da broj zaostalih predmeta nije u vezi s brojem sudaca (koji je u skladu s europskim okvirima). Kao jedan od dokaza navodi se da je stupanj rješavanja predmeta u razdoblju reforme, kada oko 800 sudaca i tužilaca nije radilo, i dalje bio iznad 100\%. To, prema autorima Funkcionalne analize pravosuđa, pokazuje da srpsko pravosuđe ima dovoljno kapaciteta (MPV, 2014: 10).

${ }^{6} \mathrm{Na}$ taj bi način, prigovaralo se, Pravosudna akademija postala ekskluzivna ulaznica u pravosuđe i mjesto na kojem bi političari ostvarivali pritisak na pravosuđe. Ta ideja je 2013. godine srušena pred Ustavnim sudom.

${ }^{7}$ Za kronologiju javne rasprave usp. članke o ustavnim promjena na https://pescanik.net/ustavsrbije/. 


\section{Hipoteze, uzorak i mjerni instrumenti}

$\mathrm{Na}$ temelju teorijsko-konceptualnog okvira rada formulirali smo nekoliko hipoteza koje bi trebale usmjeravati istraživanje veze između povjerenja u institucije pravosudnog sustava i zadovoljstva njegovim funkcioniranjem.

Opća hipoteza jest da povjerenje $u$ institucije nekog društvenog sustava (primjerice, pravosuđa) ovisi o zadovoljstvu aktera kvalitetom njegovih institucionalnih performansi (zadovoljstva kvalitetom njegove organizacije i funkcioniranja).

Posebne hipoteze su dvije: (1) ispitanici koji su zadovoljniji općim stanjem $\mathrm{u}$ pravosuđu, kvalitetom provedenih reformi koje su trebale unaprijediti njegovo funkcioniranje i usporedbom kvalitete vlastitog pravosuđa s pravosudnim sustavima razvijenih zemalja EU ujedno imaju i više povjerenja u njegove institucije, i obrnuto; (2) ispitanici zadovoljniji funkcioniranjem važnih aspekata pravosudnog sustava (sudstva, državnog odvjetništva i odvjetništva) imaju više povjerenja u njegove institucije, i obrnuto.

Anketno istraživanje, na osnovi čijih podataka su izvršene statističke analize u ovom radu, provedeno je u travnju, svibnju i lipnju 2018. godine u Hrvatskoj i Srbiji putem interneta. Sudovima, državnim odvjetništvima, odvjetničkim kancelarijama, pravnim fakultetima i profesionalnim organizacijama i udruženjima pravnika poslan je dopis s molbom da se uključe u istraživanje Pravnici i pravnička profesija $\mathrm{u} \mathrm{Hr}$ vatskoj i Srbiji kako bismo istražili izazove s kojima se pravosuđe i pravna profesija susreću u aktualnom trenutku razvoja naših društava. Sudjelovanje je bilo dobrovoljno, a anketa anonimna, pa prikupljeni podaci čine prigodni uzorak pravnika u našim zemljama. Nakon što je baza očišćena od nepotpuno ispunjenih anketa, hrvatski uzorak je obuhvatio NHR $=393$ ispitanika, a srpski uzorak NSR $=716$ ispitanika. Hrvatski uzorak obuhvaća 96 sudaca i sudskih savjetnika, 73 državna odvjetnika i zamjenika državnih odvjetnika, 68 odvjetnika i odvjetničkih vježbenika, 122 pravnika koji rade izvan pravosuđa i 34 pravna znanstvenika. Srpski uzorak obuhvaća 159 sudaca i sudskih pomoćnika, 50 tužilaca i tužilačkih pomoćnika, 272 odvjetnika i odvjetnička pripravnika, 148 pravnika izvan pravosuđa i 87 pravnih znanstvenika.

Za potrebe ovog rada iz navedenog anketnog istraživanja korišteno je nekoliko jednostavnih varijabli i nekoliko višedimenzionalnih mjernih instrumenata. Prvi instrument se sastojao od trinaest varijabli i mjerio je razinu povjerenja u različite društvene institucije (od vlade i pravosuđa do medija i sindikata). Drugi instrument se sastojao od deset varijabli u anketi provedenoj u Hrvatskoj i jedanaest u onoj provedenoj u Srbiji. Njime se mjerila razina povjerenja ispitanika u različite institucije pravosudnog sustava u širem smislu (od sudova i državnih odvjetništva do odvjetničke komore i pravosudne akademije). Treći instrument se sastojao od deset varijabli i njime se mjerila razina zadovoljstva važnim aspektima rada i funkcioniranja sudstva, državnog odvjetništva i odvjetništva. Konačno, korištene su i tri 
jednostavne varijable koje mjere razinu zadovoljstva: općim stanjem u pravosuđu, reformama koje su u pravosuđu provedene u posljednjih dvadeset godina i kvalitetom domaćeg pravosuđa u odnosu na kvalitetu pravosuđa u razvijenim zemljama EU. Ispitanici su u svim slučajevima mogli dati odgovor u teorijskom rasponu od jedan do pet, gdje veći broj predstavlja veću razinu povjerenja ili zadovoljstva. Radi lakšeg snalaženja u radu točna pojašnjenja svake kategorije mogućih odgovora i pouzdanost svake skale ili subskale navedeni su ispod tablica koje prikazuju njihove podatke ili u fusnotama u dijelu gdje se o tim skalama raspravlja.

$\mathrm{U}$ analizi podataka dobivenih na navedenim instrumentima korištene su univarijatne, bivarijatne i multivarijatne statističke procedure. Univarijatnim statističkim postupcima prikazani su postoci distribucije odgovora na pojedina pitanja, aritmetičke sredine te standardne devijacije, a bivarijatnom analizom (jednostavnom analizom varijance $)^{8}$ testirana je značajnost razlika između skupina ispitanika. Multivarijatne analize (faktorska i regresijska analiza) korištene su kako bi se utvrdilo postojanje latentnih dimenzija na korištenim instrumentima te u kojoj mjeri zadovoljstvo stanjem u pravosuđu i funkcioniranjem njegovih važnih aspekata objašnjava povjerenje u pravosuđe i njegove institucije.

\section{Povjerenje u institucije u društvu i državi}

Povjerenje u institucije je mjera njihove legitimnosti i djelotvornosti. Ali, kada se povjerenje promatra u kontekstu same institucije i ljudi koji u njoj rade, ono je i pokazatelj "institucionalnog zdravlja", tj. njene "unutarnje" legitimnosti. Mi smo u ovom istraživanju mjerili povjerenje pripadnika pravničkih profesija u šire društvene i političke institucije, kao i specifične institucije pravosudnog sustava. U ovom odjeljku iznosimo stavove prema tim institucijama ukazujući na osnovne razlike u stavovima prema pojedinim institucijama i grupama institucija s jedne te na razlike među pripadnicima različitih profesija s druge strane.

Čak i letimičan pregled dobivenih rezultata (tablica 1 na sljedećoj stranici) jasno ukazuje da se suočavamo s rasprostranjenom skepsom u pogledu najvažnijih političkih i društvenih institucija. Rezultati aritmetičkih sredina u pravilu su ispod teorijskog prosjeka skale, a broj ispitanika koji nemaju povjerenja u institucije (kategorije 1 i 2) u velikoj većini slučajeva veći je od broja ispitanika koji u njih imaju povjerenja (kategorije 4 i 5). ${ }^{9}$ Iako između država postoje manje razlike s obzirom

${ }^{8}$ Za svaku analizu varijance najprije je proveden test homogenosti varijance, testiran F-omjer te su provedeni post-hoc testovi multiple komparacije. U slučaju homogenih varijanci korišten je Scheffeov, a u slučaju nehomogenih Tamhaneov T2 test.

${ }^{9}$ Kada se u nastavku rada bude raspravljalo o broju ispitanika koji nemaju povjerenje $\mathrm{u}$ institucije, govorit ćemo o zbroju ispitanika koji su odabrali kategorije 1 i 2, a kada budemo govorili o onima koji imaju povjerenje, referirat ćemo se na kategorije 4 i 5. 
Tablica 1. Povjerenje u institucije

\begin{tabular}{|c|c|c|c|c|c|c|c|}
\hline Povjerenje u: & Republika & 1 & 2 & 3 & 4 & 5 & M (SD) \\
\hline Hrvatski sabor & Hrvatska & $28,38 \%$ & $31,62 \%$ & $32,70 \%$ & $6,76 \%$ & $0,54 \%$ & $2,19(0,95)$ \\
\hline Narodnu skupštinu & Srbija & $41,32 \%$ & $25,41 \%$ & $22,67 \%$ & $8,23 \%$ & $2,38 \%$ & $2,05(1,09)$ \\
\hline \multirow{2}{*}{ Vladu } & Hrvatska & $27,10 \%$ & $33,33 \%$ & $30,35 \%$ & $8,40 \%$ & $0,81 \%$ & $2,22(0,97)$ \\
\hline & Srbija & $40,95 \%$ & $23,77 \%$ & $22,49 \%$ & $9,32 \%$ & $3,47 \%$ & $2,11(1,15)$ \\
\hline Političke stranke & Hrvatska & $48,36 \%$ & $32,24 \%$ & $17,76 \%$ & $1,64 \%$ & $0,00 \%$ & $1,73(0,81)$ \\
\hline Političke partije & Srbija & $61,20 \%$ & $22,95 \%$ & $12,93 \%$ & $1,82 \%$ & $1,09 \%$ & $1,59(0,86)$ \\
\hline \multirow{2}{*}{$\begin{array}{l}\text { Lokalnu } \\
\text { samoupravu }\end{array}$} & Hrvatska & $27,84 \%$ & $31,08 \%$ & $33,51 \%$ & $7,03 \%$ & $0,54 \%$ & $2,21(0,95)$ \\
\hline & Srbija & $38,86 \%$ & $30,94 \%$ & $23,20 \%$ & $5,16 \%$ & $1,84 \%$ & $2,00(1,00)$ \\
\hline \multirow{2}{*}{ Vojsku } & Hrvatska & $16,53 \%$ & $16,80 \%$ & $33,88 \%$ & $27,82 \%$ & $4,96 \%$ & $2,88(1,14)$ \\
\hline & Srbija & $19,12 \%$ & $18,75 \%$ & $32,90 \%$ & $24,26 \%$ & $4,96 \%$ & $2,77(1,16)$ \\
\hline \multirow{2}{*}{ Pravosuđe } & Hrvatska & $11,48 \%$ & $22,13 \%$ & $33,61 \%$ & $30,33 \%$ & $2,46 \%$ & $2,90(1,04)$ \\
\hline & Srbija & $11,90 \%$ & $22,16 \%$ & $32,60 \%$ & $28,21 \%$ & $5,13 \%$ & $2,92(1,09)$ \\
\hline \multirow{2}{*}{ Policiju } & Hrvatska & $12,20 \%$ & $15,99 \%$ & $36,59 \%$ & $33,06 \%$ & $2,17 \%$ & $2,97(1,03)$ \\
\hline & Srbija & $16,51 \%$ & $23,85 \%$ & $34,86 \%$ & $21,47 \%$ & $3,30 \%$ & $2,71(1,08)$ \\
\hline \multirow{2}{*}{ Ombudsmana } & Hrvatska & $12,26 \%$ & $16,62 \%$ & $41,96 \%$ & $25,61 \%$ & $3,54 \%$ & $2,92(1,02)$ \\
\hline & Srbija & $17,71 \%$ & $19,00 \%$ & $36,90 \%$ & $21,96 \%$ & $4,43 \%$ & $2,76(1,11)$ \\
\hline \multirow{2}{*}{ Crkvu } & Hrvatska & $39,84 \%$ & $16,80 \%$ & $28,18 \%$ & $12,20 \%$ & $2,98 \%$ & $2,22(1,18)$ \\
\hline & Srbija & $25,09 \%$ & $16,67 \%$ & $32,05 \%$ & $19,05 \%$ & $7,14 \%$ & $2,66(1,24)$ \\
\hline \multirow{2}{*}{ Medije } & Hrvatska & $36,61 \%$ & $33,33 \%$ & $24,59 \%$ & $5,19 \%$ & $0,27 \%$ & $1,99(0,92$ \\
\hline & Srbija & $44,85 \%$ & $34,93 \%$ & $17,28 \%$ & $1,65 \%$ & $1,29 \%$ & $1,80(0,87)$ \\
\hline \multirow{2}{*}{ Sindikate } & Hrvatska & $36,41 \%$ & $30,43 \%$ & $28,53 \%$ & $3,80 \%$ & $0,82 \%$ & $2,02(0,94)$ \\
\hline & Srbija & $42,20 \%$ & $31,38 \%$ & $21,10 \%$ & $4,04 \%$ & $1,10 \%$ & $1,97(1,92)$ \\
\hline \multirow{2}{*}{$\begin{array}{l}\text { Nevladine } \\
\text { organizacije }\end{array}$} & Hrvatska & $25,96 \%$ & $21,58 \%$ & $40,71 \%$ & $11,20 \%$ & $0,55 \%$ & $2,39(1,01)$ \\
\hline & Srbija & $37,89 \%$ & $22,77 \%$ & $30,05 \%$ & $7,47 \%$ & $1,82 \%$ & $2,13(1,06)$ \\
\hline \multirow{2}{*}{ EU } & Hrvatska & $14,05 \%$ & $14,59 \%$ & $45,68 \%$ & $23,51 \%$ & $2,16 \%$ & $2,85(1,01)$ \\
\hline & Srbija & $32,25 \%$ & $21,38 \%$ & $32,97 \%$ & $10,69 \%$ & $2,72 \%$ & $2,30(1,11)$ \\
\hline
\end{tabular}

1 = uopće nemam povjerenja; 2 = uglavnom nemam povjerenja; 3 = niti imam niti nemam povjerenja; $4=$ uglavnom imam povjerenja; $5=$ u potpunosti imam povjerenja 
na stupanj (ne)povjerenja u pojedine institucije, generalni trend nepovjerenja $u$ institucije u njima vrlo je sličan. ${ }^{10}$

$\mathrm{Na}$ osnovi rezultata faktorske analize, institucije su grupirane na sljedeći način: (1) parlament, vlada, stranke i lokalna samouprava čine institucije državno-političkog sustava; (2) pravosuđe, policija i ombudsman čine institucije pravosudno-represivnog sustava; a (3) mediji, sindikati i NVO čine institucije građanskog društva. ${ }^{11}$ Budući da su faktorske analize pokazale da se povjerenje u crkvu, vojsku i EU u hrvatskom i srpskom uzorku ne smještaju unutar istih faktora, povjerenje $u$ te institucije prikazat ćemo odvojeno.

Razina povjerenja u institucije državno-političkog sustava u obje zemlje je niska $(M H R=2,08 ;$ MSR $=1,91)$. Najniže je povjerenje u političke stranke - više od $80 \%$ ispitanika tvrdi da u njih nema povjerenja. Oko dvije trećine ispitanika nema povjerenje u parlamente, vlade i lokalne samouprave. Koliko je nizak stupanj povjerenja u te institucije možda najjasnije pokazuje podatak da je broj ispitanika u obje zemlje koji eksplicitno iskazuju povjerenje u njih najveći u kontekstu povjerenja u vladu, a da je istovremeno postotak tih ispitanika samo $12,79 \%$ u Srbiji i svega 9,12\% u Hrvatskoj.

Povjerenje u institucije građanskog društva u prosjeku je tek nešto malo više nego u institucije državno-političkog sustava (MHR =2,11; MSR =1,94). Stupanj povjerenja u sindikate i medije je vrlo nizak i ne prelazi 6\% u Hrvatskoj i 3\% u Srbiji. Nije puno bolja situacija ni s nevladinim organizacijama: tek svaki deseti ispitanik u obje zemlje ima povjerenje u njih, istovremeno u njih nepovjerenje iskazuje čak $60 \%$ srpskih i $47 \%$ hrvatskih ispitanika.

Konačno, povjerenje u institucije pravosudno-represivnog sustava nešto je veće nego u prethodnim slučajevima $(\mathrm{MHR}=2,93$; $\mathrm{MSR}=2,81)$. U obje zemlje pravosuđe, policija i ombudsman spadaju u institucije u koje ispitanici imaju u relativnom smislu "više povjerenja" - grubo govoreći, u njih ima povjerenje između jedne četvrtine $\mathrm{i}$ jedne trećine ispitanika. Iako se i ovdje razina povjerenja nalazi ispod teorijskog prosjeka skale, ispada da su ispitanici najmanje kritični prema pravosuđu.

U sljedećem koraku analizirali smo razlike u povjerenju u navedene skupine institucija između pripadnika različitih pravničkih profesija. Analiza varijance (tablica 2) pokazuje da sve profesije u prosjeku nemaju povjerenja u institucije državno-političkog sustava i institucije građanskog društva te da pojedine profesije u

${ }^{10}$ Faktorska analiza je u obje zemlje pokazala da se varijable instrumenta koji mjeri povjerenje $\mathrm{u}$ institucije grupiraju u tri latentne dimenzije. U Hrvatskoj te tri dimenzije zajedno objašnjavaju $61,94 \%$ ukupne varijance instrumenta, a u Srbiji 66,54\%.

11 Rezultati Cronbachovog $\alpha$ testa pokazuju da je pouzdanost svih skala zadovoljavajuća u obje zemlje. Pouzdanost je prve skale u hrvatskom uzorku 0,858, a u srpskom 0,896; druge skale 0,787 u hrvatskom i 0,767 u srpskom; a treće 0,709 u hrvatskom i 0,564 u srpskom. 
prosjeku imaju povjerenja u pravosudni sustav. $U$ obje zemlje odvjetnici u pravilu pokazuju najviše nepovjerenja u institucije, dok su suci i državni odvjetnici manje kritični prema njima. Oni pokazuju nešto veći stupanj povjerenja (iznad teorijskog prosjeka skale) u institucije pravosudnog sustava, kao i u pravosuđe generalno gledano, te manji stupanj nepovjerenja u institucije državno-političkog sustava.

Tablica 2. Analiza varijance - povjerenje u institucije različitih pravničkih profesija

\begin{tabular}{|c|c|c|c|c|c|c|c|c|}
\hline $\begin{array}{l}\text { Povjerenje } \\
\text { u institucije: }\end{array}$ & $\begin{array}{l}\text { Repub- } \\
\text { lika }\end{array}$ & Suci & $\begin{array}{c}\text { Državni } \\
\text { odvjetnici }\end{array}$ & $\begin{array}{l}\text { Odvjet- } \\
\text { nici }\end{array}$ & $\begin{array}{c}\text { Pravni } \\
\text { znanstve- } \\
\text { nici }\end{array}$ & Ostali & $F(p)$ & Post-hoc \\
\hline \multirow{2}{*}{$\begin{array}{l}\text { Državno- } \\
\text { političkog } \\
\text { sustava }\end{array}$} & Hrvatska & $\begin{array}{c}2,30 \\
(0,80)\end{array}$ & $\begin{array}{c}2,02 \\
(0,82)\end{array}$ & $\begin{array}{c}1,98 \\
(0,72)\end{array}$ & $\begin{array}{c}2,01 \\
(0,69)\end{array}$ & $\begin{array}{c}2,00 \\
(0,76)\end{array}$ & $\begin{array}{l}2,676 \\
(0,03)\end{array}$ & \\
\hline & Srbija & $\begin{array}{c}2,23 \\
(1,03)\end{array}$ & $\begin{array}{c}2,54 \\
(1,03)\end{array}$ & $\begin{array}{c}1,58 \\
(0,64)\end{array}$ & $\begin{array}{c}1,81 \\
(0,74)\end{array}$ & $\begin{array}{c}1,99 \\
(0,88)\end{array}$ & $\begin{array}{l}20,107 \\
(0,00)\end{array}$ & $\begin{array}{c}1>3,4 \text { i } 5 \\
2>3,4 \text { i } 5 \\
5>3\end{array}$ \\
\hline \multirow{2}{*}{$\begin{array}{l}\text { Pravosudno- } \\
\text { represivnog } \\
\text { sustava }\end{array}$} & Hrvatska & $\begin{array}{c}3,27 \\
(0,79)\end{array}$ & $\begin{array}{c}3,12 \\
(0,84) \\
\end{array}$ & $\begin{array}{c}2,62 \\
(0,83) \\
\end{array}$ & $\begin{array}{c}2,98 \\
(0,65) \\
\end{array}$ & $\begin{array}{c}2,11 \\
(0,77)\end{array}$ & $\begin{array}{l}8,619 \\
(0,00)\end{array}$ & $\begin{array}{l}1>3 \text { i } 5 \\
2>3 \text { i } 5\end{array}$ \\
\hline & Srbija & $\begin{array}{c}3,20 \\
(0,88)\end{array}$ & $\begin{array}{c}3,41 \\
(0,80)\end{array}$ & $\begin{array}{c}2,51 \\
(0,80) \\
\end{array}$ & $\begin{array}{c}2,70 \\
(0,86) \\
\end{array}$ & $\begin{array}{c}2,11 \\
(0,77)\end{array}$ & $\begin{array}{l}13,332 \\
(0,00) \\
\end{array}$ & $\begin{array}{l}1>3,4 \text { i } 5 \\
2>3,4 \text { i } 5\end{array}$ \\
\hline \multirow{2}{*}{$\begin{array}{l}\text { Građanskog } \\
\text { društva }\end{array}$} & Hrvatska & $\begin{array}{l}2,15 \\
(0,72)\end{array}$ & $\begin{array}{c}2,09 \\
(0,75) \\
\end{array}$ & $\begin{array}{c}1,91 \\
(0,81)\end{array}$ & $\begin{array}{c}2,47 \\
(0,69) \\
\end{array}$ & $\begin{array}{c}2,11 \\
(0,77)\end{array}$ & $\begin{array}{l}2,940 \\
(0,02) \\
\end{array}$ & $4>3$ \\
\hline & Srbija & $\begin{array}{c}2,21 \\
(1,37) \\
\end{array}$ & $\begin{array}{c}2,29 \\
(0,91) \\
\end{array}$ & $\begin{array}{c}1,71 \\
(0,65) \\
\end{array}$ & $\begin{array}{c}1,87 \\
(0,66) \\
\end{array}$ & $\begin{array}{c}1,93 \\
(0,77)\end{array}$ & $\begin{array}{l}8,174 \\
(0,00) \\
\end{array}$ & $\begin{array}{l}1>3 \\
2>3\end{array}$ \\
\hline \multirow{2}{*}{$\begin{array}{l}\text { Pravosuđa } \\
\text { (pojedinačna } \\
\text { varijabla) }\end{array}$} & Hrvatska & $\begin{array}{c}3,38 \\
(0,90) \\
\end{array}$ & $\begin{array}{c}3,17 \\
(1,00)\end{array}$ & $\begin{array}{c}2,54 \\
(1,01)\end{array}$ & $\begin{array}{c}2,89 \\
(0,88)\end{array}$ & $\begin{array}{c}2,52 \\
(1,03) \\
\end{array}$ & $\begin{array}{l}13,422 \\
(0,00)\end{array}$ & $\begin{array}{l}1>3 \text { i } 5 \\
2>3 \text { i } 5\end{array}$ \\
\hline & Srbija & $\begin{array}{c}3,56 \\
(1,00)\end{array}$ & $\begin{array}{c}3,51 \\
(0,90)\end{array}$ & $\begin{array}{c}2,54 \\
(0,96)\end{array}$ & $\begin{array}{c}2,66 \\
(1,03)\end{array}$ & $\begin{array}{c}2,72 \\
(1,05)\end{array}$ & $\begin{array}{c}28,986 \\
(0,00)\end{array}$ & $\begin{array}{l}1>3,4 \text { i } 5 \\
2>3,4 \text { i } 5\end{array}$ \\
\hline
\end{tabular}

Za svaku kategoriju zanimanja prikazane su vrijednosti aritmetičkih sredina i standardnih devijacija - M (SD).

\section{Povjerenje u pravosudne institucije}

Kada je riječ o povjerenju u pravosudne institucije ${ }^{12}$ (tablica 3), ispitanici iz obje zemlje u velikoj većini slučajeva postižu rezultate ispod teorijskog prosjeka skale. Izuzetak od tog trenda je povjerenje u sudove. I u Hrvatskoj i u Srbiji više je anketiranih pravnika koji imaju povjerenja u sudove (41\% u Hrvatskoj, a 38\% u Srbiji)

12 Pouzdanost te skale u okviru hrvatskog uzorka iznosi 0,897, a u okviru srpskog uzorka 0,910. 
od onih koji ga nemaju (u Srbiji 24\%, a u Hrvatskoj 23\%). Pored toga, u Srbiji ispitanici imaju više povjerenja u Društvo sudija Srbije (37\% ispitanika ima povjerenja, a $22 \%$ nema) i odvjetničke urede ( $29 \%$ prema $19 \%$ ). U Hrvatskoj ispitanici postižu prosječne vrijednosti iznad teorijskog prosjeka skale u slučaju povjerenja u javne bilježnike (47\% prema $15 \%)$, državna odvjetništva (40\% prema $23 \%$ ) i zatvorski sustav (29\% prema 22\%). Ipak, vidljivo je da u obje zemlje čak i u navedenim slučajevima ispitanici u prosjeku iskazuju neutralno ili tek blago pozitivno povjerenje.

Tablica 3. Povjerenje u pravosudne institucije

\begin{tabular}{|c|c|c|c|c|c|c|c|}
\hline Povjerenje u: & Republika & 1 & 2 & 3 & 4 & 5 & M (SD) \\
\hline $\begin{array}{l}\text { Hrvatsku odvjetničku } \\
\text { komoru }\end{array}$ & Hrvatska & $13,26 \%$ & $18,04 \%$ & $47,75 \%$ & $18,83 \%$ & $2,12 \%$ & $\begin{array}{c}2,79 \\
(0,97)\end{array}$ \\
\hline $\begin{array}{l}\text { Advokatsku komoru } \\
\text { Srbije }\end{array}$ & Srbija & $15,66 \%$ & $19,28 \%$ & $42,17 \%$ & $18,59 \%$ & $4,30 \%$ & $\begin{array}{c}2,77 \\
(1,06)\end{array}$ \\
\hline Udrugu hrvatskih sudaca & Hrvatska & $15,87 \%$ & $14,02 \%$ & $50,53 \%$ & $16,67 \%$ & $2,91 \%$ & $\begin{array}{c}2,77 \\
(1,00)\end{array}$ \\
\hline \multirow[t]{2}{*}{ Društvo sudija Srbije } & Srbija & $10,00 \%$ & $12,41 \%$ & $40,34 \%$ & $25,52 \%$ & $11,72 \%$ & $\begin{array}{c}3,17 \\
(1,11)\end{array}$ \\
\hline & Hrvatska & - & - & - & - & - & - \\
\hline Udruženje tužilaca Srbije & Srbija & $13,24 \%$ & $13,59 \%$ & $42,68 \%$ & $21,78 \%$ & $8,71 \%$ & $\begin{array}{c}2,99 \\
(1,11)\end{array}$ \\
\hline $\begin{array}{l}\text { Odvjetničke urede/ } \\
\text { društva }\end{array}$ & Hrvatska & $10,08 \%$ & $18,83 \%$ & $47,48 \%$ & $22,81 \%$ & $0,80 \%$ & $\begin{array}{c}2,85 \\
(0,91) \\
\end{array}$ \\
\hline Advokatske kancelarije & Srbija & $6,07 \%$ & $13,52 \%$ & $51,30 \%$ & $25,65 \%$ & $3,47 \%$ & $\begin{array}{c}3,07 \\
(0,88) \\
\end{array}$ \\
\hline Državna odvjetništva & Hrvatska & $7,16 \%$ & $16,18 \%$ & $37,67 \%$ & $32,89 \%$ & $6,10 \%$ & $\begin{array}{c}3,15 \\
(1,00)\end{array}$ \\
\hline Tužilaštva & Srbija & $14,51 \%$ & $19,76 \%$ & $40,03 \%$ & $21,15 \%$ & $4,55 \%$ & $\begin{array}{c}2,81 \\
(1,07)\end{array}$ \\
\hline \multirow{2}{*}{ Sudove } & Hrvatska & $7,18 \%$ & $16,22 \%$ & $35,11 \%$ & $38,03 \%$ & $3,46 \%$ & $\begin{array}{c}3,14 \\
(0,97)\end{array}$ \\
\hline & Srbija & $8,12 \%$ & $16,41 \%$ & $37,48 \%$ & $31,09 \%$ & $6,91 \%$ & $\begin{array}{c}3,12 \\
(1,03)\end{array}$ \\
\hline Javnobilježničke urede & Hrvatska & $5,91 \%$ & $9,41 \%$ & $36,83 \%$ & $43,55 \%$ & $4,30 \%$ & $\begin{array}{c}3,31 \\
(0,92)\end{array}$ \\
\hline $\begin{array}{l}\text { Javno-beležničke } \\
\text { kancelarije }\end{array}$ & Srbija & $11,28 \%$ & $14,93 \%$ & $45,14 \%$ & $23,61 \%$ & $5,03 \%$ & $\begin{array}{c}2,96 \\
(1,02)\end{array}$ \\
\hline
\end{tabular}




\begin{tabular}{l|l|llllll}
\hline Državno sudbeno vijeće & Hrvatska & $18,83 \%$ & $19,89 \%$ & $42,71 \%$ & $17,51 \%$ & $1,06 \%$ & $\begin{array}{c}2,62 \\
(1,01)\end{array}$ \\
\hline Visoki savet sudstva & Srbija & $14,91 \%$ & $18,25 \%$ & $40,88 \%$ & $19,12 \%$ & $6,84 \%$ & $\begin{array}{c}2,85 \\
(1,11)\end{array}$ \\
\hline $\begin{array}{l}\text { Državnoodvjetničko } \\
\text { vijeće }\end{array}$ & Hrvatska & $15,03 \%$ & $15,30 \%$ & $47,54 \%$ & $18,03 \%$ & $4,10 \%$ & $\begin{array}{c}2,81 \\
(1,03)\end{array}$ \\
\hline \multirow{2}{*}{$\begin{array}{l}\text { Državno veće tužilaca } \\
\text { Pravosudnu akademiju }\end{array}$} & Srbija & $16,67 \%$ & $15,80 \%$ & $44,27 \%$ & $16,84 \%$ & $6,42 \%$ & $\begin{array}{c}2,81 \\
(1,10)\end{array}$ \\
\cline { 2 - 7 } & Hrvatska & $14,40 \%$ & $13,60 \%$ & $45,33 \%$ & $22,67 \%$ & $4,00 \%$ & $\begin{array}{c}2,88 \\
(1,04)\end{array}$ \\
\hline \multirow{2}{*}{ Zatvorski sustav } & Srbija & $32,06 \%$ & $19,58 \%$ & $35,88 \%$ & $8,15 \%$ & $4,33 \%$ & $\begin{array}{c}2,33 \\
(1,13)\end{array}$ \\
\hline & Hrvatska & $6,88 \%$ & $15,87 \%$ & $48,15 \%$ & $26,72 \%$ & $2,38 \%$ & $\begin{array}{c}3,02 \\
(0,89)\end{array}$ \\
\cline { 2 - 7 } & Srbija & $13,00 \%$ & $20,80 \%$ & $45,93 \%$ & $16,46 \%$ & $3,81 \%$ & $\begin{array}{c}2,77 \\
(1,00)\end{array}$ \\
\hline
\end{tabular}

1 = uopće nemam povjerenja; 2 = uglavnom nemam povjerenja; 3 = niti imam niti nemam povjerenja; $4=$ uglavnom imam povjerenja; $5=$ u potpunosti imam povjerenja

Rezultati faktorske analize pokazali su da se varijable tog instrumenta u obje zemlje grupiraju unutar dvije latentne dimenzije. Na osnovu njih su napravljene kompozitne varijable. U "nedržavne" pravosudne institucije u srpskom uzorku $(\mathrm{MSR}=2,97)$ spadaju advokatske kancelarije, Advokatska komora Srbije, Društvo sudija Srbije i Udruženje tužilaca Srbije. U hrvatskom uzorku (MHR = 2,79) ta je kompozitna varijabla obuhvatila odvjetničke kancelarije, Hrvatsku odvjetničku komoru i Udrugu hrvatskih sudaca. U "državne" pravosudne institucije u obje zemlje $(\mathrm{MHR}=2,91 ; \mathrm{MSR}=2,75)$ spadaju preostale varijable tog instrumenta: sudovi, državna odvjetništva, zatvori, pravosudne akademije i državna vijeća sudstva i državnih odvjetništava. ${ }^{13}$ Kako bi se testiralo postoje li između pripadnika različitih pravnih profesija razlike $u$ razini povjerenja u navedene skupine institucija, provedene su analize varijance.

Rezultati pokazuju da u obje zemlje postoje razlike između pojedinih pravničkih profesija (tablica 4). U hrvatskom uzorku izdvajaju se državni odvjetnici kao grupa koja u prosjeku ima više povjerenja u "državne" pravosudne institucije od drugih pravnih profesija, a u srpskom uzorku, pored njih, viši stupanj povjerenja od

${ }^{13}$ U Hrvatskoj te dvije dimenzije zajedno objašnjavaju 63,36\%, a u Srbiji 64,13\% ukupne varijance instrumenta. Pouzdanost skale "nedržavnih" institucija u srpskom uzorku je 0,791, a u hrvatskom 0,799. Rezultat Cronbachovog $\alpha$ testa provedenog na subskali povjerenja u "državne" pravosudne institucije u okviru hrvatskog uzorka iznosi 0,880 , a u okviru srpskog uzorka 0,897. 
Tablica 4. Analiza varijance - povjerenje u pravosudne institucije među pravničkim profesijama

\begin{tabular}{l|l|ccccccc}
\hline $\begin{array}{l}\text { Povjerenje } \\
\text { u: }\end{array}$ & $\begin{array}{l}\text { Repub- } \\
\text { lika }\end{array}$ & Suci & $\begin{array}{c}\text { Državni } \\
\text { odvjet- } \\
\text { nici }\end{array}$ & $\begin{array}{c}\text { Odvjet- } \\
\text { nici }\end{array}$ & $\begin{array}{c}\text { Pravni } \\
\text { znanstve- } \\
\text { nici }\end{array}$ & Ostali & F (p) & Post-hoc \\
\hline \multirow{2}{*}{$\begin{array}{l}\text { "Državne" } \\
\text { pravosudne } \\
\text { institucije }\end{array}$} & Hrvatska & $\begin{array}{c}3,02 \\
(0,78)\end{array}$ & $\begin{array}{c}3,25 \\
(0,81)\end{array}$ & $\begin{array}{c}2,68 \\
(0,80)\end{array}$ & $\begin{array}{c}2,79 \\
(0,67)\end{array}$ & $\begin{array}{c}2,75 \\
(0,81)\end{array}$ & $\begin{array}{c}6,533 \\
(0,00)\end{array}$ & $2>3$ i 5 \\
\cline { 2 - 9 } & Srbija & 3,09 & 3,55 & 2,49 & 2,52 & 2,68 & 23,811 & $1>3,4$ i 5 \\
& $(0,97)$ & $(0,68)$ & $(0,77)$ & $(0,73)$ & $(0,91)$ & $(0,00)$ & $2>1,3,4$ i 5 \\
\hline \multirow{2}{*}{$\begin{array}{l}\text { Nedržavne" } \\
\text { pravosudne } \\
\text { institucije }\end{array}$} & Hrvatska & $\begin{array}{c}2,87 \\
(0,84)\end{array}$ & $\begin{array}{c}2,67 \\
(0,82)\end{array}$ & $\begin{array}{c}3,08 \\
(0,69)\end{array}$ & $\begin{array}{c}2,62 \\
(0,73)\end{array}$ & $\begin{array}{c}2,68 \\
(0,84)\end{array}$ & $\begin{array}{c}3,718 \\
(0,01)\end{array}$ & $3>2$ i 5 \\
\cline { 2 - 9 } & Srbija & $\begin{array}{c}3,11 \\
(0,94)\end{array}$ & $\begin{array}{c}3,31 \\
(0,77)\end{array}$ & $\begin{array}{c}2,95 \\
(0,71)\end{array}$ & $\begin{array}{c}2,95 \\
(0,72)\end{array}$ & $\begin{array}{c}2,72 \\
(0,72)\end{array}$ & $\begin{array}{c}5,788 \\
(0,00)\end{array}$ & $2>4$ i 5 \\
\hline
\end{tabular}

ostalih imaju i suci. S druge strane, odvjetnici i pravnici izvan pravosuđa imaju najmanji stupanj povjerenja u te institucije. ${ }^{14}$ Drugi važan nalaz je da srpski odvjetnici, znanstvenici i pravnici koji rade izvan pravosuđa pokazuju nešto više nepovjerenja prema "državnim” pravosudnim institucijama od svojih hrvatskih kolega. Razlika između rezultata iz hrvatskog i srpskog uzorka postoji i u kontekstu povjerenja $u$ "nedržavne" institucije pravosudnog sustava. U hrvatskom uzorku odvjetnici imaju nešto više povjerenja u te institucije od državnih odvjetnika i pravnika izvan pravosuđa, a u srpskom uzorku državni odvjetnici i suci imaju više povjerenja u njih od pravnih znanstvenika i pravnika izvan pravosuđa. ${ }^{15}$

14 Razlike u rezultatima između Hrvatske i Srbije javljaju se iz nekoliko razloga. Prvo, suci i tužitelji iz srpskog uzorka postižu nešto više rezultate na većem broju varijabli koji konstituiraju tu kompozitnu varijablu od sudaca i državnih odvjetnika u hrvatskom uzorku. Drugo, u srpskom uzorku se između sudaca i tužioca javljaju veće razlike u razini povjerenja u kontekstu većeg broja institucija koji čine tu kompozitnu varijablu nego što je to slučaj između sudaca i državnih odvjetnika u hrvatskom uzorku.

15 Razlike između Hrvatske i Srbije treba tražiti i u činjenici da se ta kompozitna varijabla u hrvatskom uzorku sastoji od tri, a u srpskom od četiri varijable. U srpskom uzorku je obuhvaćeno povjerenje i u Udruženje tužilaca Srbije. Budući da u tu instituciju i tužioci $(\mathrm{M}=3,77)$ i suci $(\mathrm{M}=3,48)$ u prosjeku imaju dosta povjerenja, to se odražava i na prosječnu vrijednost. Uz to, u srpskom uzorku se pokazuje da suci $(M=3,76)$ i tužioci $(M=3,77)$ imaju više povjerenja u Društvo sudija Srbije nego što u hrvatskom uzorku suci $(\mathrm{M}=3,12)$ i državni odvjetnici $(\mathrm{M}=2,74)$ imaju u Udrugu hrvatskih sudaca. Istovremeno odvjetnici u Hrvatskoj imaju bitno više povjerenja u Hrvatsku odvjetničku komoru $(M=3,48)$ nego što odvjetnici u Srbiji imaju u Advokatsku komoru Srbije $(M=3,00)$. Sve navedeno nedvosmisleno utječe na to da u Srbiji u relativnom smislu tužioci i suci imaju viši stupanj povjerenja u "nedržavne" pravosudne institucije, a da u Hrvatskoj odvjetnici u relativnom smislu imaju više povjerenja u te institucije od drugih kategorija pravnika. 
Ukupno gledano, prikazani podaci pokazuju da pravosudne sustave u obje države odlikuje nepovjerenje u njihove institucije velikog broja aktera koji su s njima u doticaju. Institucionalno nepovjerenje posebno je izraženo kod aktera koji su neovisni u odnosu na pravosudni sustav. To objašnjavamo kao neovisnu procjenu njegovog rada, ali i kao posljedicu generalno niskog institucionalnog povjerenja i raširene društvene i političke skepse. S druge strane, vjerujemo da se u relativnom smislu nešto viša razina povjerenja u pravosuđe i institucije pravosudnog sustava koje iskazuju suci i državni odvjetnici može barem jednim dijelom objasniti njihovom manjom (samo)kritičnosti, koja proizlazi iz toga što su ocjenjivali povjerenje $u$ sustave kojih su i sami dio i koji su utjecali na oblikovanje njihovih profesionalnih identiteta i stavova.

\section{Zadovoljstvo radom i stanjem u pravosuđu}

Sliku (ne)povjerenja u pravosudne i druge institucije nadopunjuju stavovi o zadovoljstvu stanjem u pravosuđu, reformama i kvalitetom pravosudnih sustava u odnosu na zemlje EU. Naime, pokazuje se da anketirani pravnici nisu zadovoljni stanjem u pravosuđu i reformama koje su u njihovim državama provedene u posljednjih dvadeset godina. Čak 48\% ispitanika u Hrvatskoj i 45\% ispitanika u Srbiji tvrdi da je nezadovoljno stanjem u pravosuđu (kategorija 2), a dodatnih 23\% u Srbiji i 19\% u Hrvatskoj da je tim stanjem vrlo nezadovoljno (kategorija 1). Istovremeno samo 7\% ispitanika u Hrvatskoj i 5\% u Srbiji tvrdi da je stanjem u pravosuđu zadovoljno (kategorija 4). Stupanj nezadovoljstva stanjem u pravosuđu možda najbolje pokazuje činjenica da je u Srbiji tek 0,5\% anketiranih ispitanika njime vrlo zadovoljno, a u Hrvatskoj nijedan ispitanik.

Tablica 5. Zadovoljstvo reformama i općim stanjem u pravosuđu

\begin{tabular}{l|l|cccccc}
\hline & Republika & $\mathbf{1}$ & $\mathbf{2}$ & $\mathbf{3}$ & $\mathbf{4}$ & $\mathbf{5}$ & M (SD) \\
\hline $\begin{array}{l}\text { Koliko ste zadovoljni } \\
\text { reformama koje su u } \\
\text { pravosuđu provedene u } \\
\text { posljednjih 20 godina? }\end{array}$ & Hrvatska & $20,10 \%$ & $46,00 \%$ & $28,60 \%$ & $5,30 \%$ & $0,00 \%$ & $\begin{array}{c}2,19 \\
(0,82)\end{array}$ \\
\cline { 2 - 7 } & Srbija & $29,02 \%$ & $40,76 \%$ & $25,22 \%$ & $4,66 \%$ & $0,35 \%$ & $\begin{array}{c}2,07 \\
(0,87)\end{array}$ \\
\hline $\begin{array}{l}\text { Koliko ste općenito } \\
\begin{array}{l}\text { zadovoljni stanjem u } \\
\text { našem pravosuđu? }\end{array}\end{array}$ & Hrvatska & $19,30 \%$ & $48,10 \%$ & $24,90 \%$ & $7,70 \%$ & $0,00 \%$ & $\begin{array}{c}2,21 \\
(0,84)\end{array}$ \\
\cline { 2 - 7 } & Srbija & $23,12 \%$ & $45,03 \%$ & $25,86 \%$ & $5,48 \%$ & $0,51 \%$ & $\begin{array}{c}2,15 \\
(0,86)\end{array}$ \\
\hline
\end{tabular}

$1=$ vrlo nezadovoljan; 2 = nezadovoljan; $3=$ ni zadovoljan ni nezadovoljan; 4 = zadovoljan; $5=$ vrlo zadovoljan 
Situacija je slična i kada je riječ o nezadovoljstvu ispitanika reformama koje su u pravosuđu provedene u posljednjih dvadeset godina. U obje zemlje dva od tri ispitanika tvrdi da provedenim reformama nisu zadovoljni, jedan od četiri ispitanika da tim reformama nije ni zadovoljan ni nezadovoljan, a tek 7\% ispitanika u Hrvatskoj i $6 \%$ ispitanika u Srbiji tvrdi da je reformama zadovoljno. ${ }^{16}$ Još lošije rezultate daje usporedba kvalitete domaćih pravosuđa sa zemljama EU. U obje zemlje velika većina ispitanika svoje sustave ocjenjuje kao lošije, oko četvrtine uzorka čine neodlučni, a tek oko $1 \%$ ispitanika misli da su hrvatski i srpski sustavi bolji.

Tablica 6. Percepcija pravosudnih sustava u odnosu na razvijene zemlje EU

\begin{tabular}{l|l|cccccc}
\hline & Republika & $\mathbf{1}$ & $\mathbf{2}$ & $\mathbf{3}$ & $\mathbf{4}$ & $\mathbf{5}$ & M (SD) \\
\hline $\begin{array}{l}\text { Po Vašem mišljenju, kakva } \\
\text { je kvaliteta funkcioniranja } \\
\text { našeg pravosudnog sustava }\end{array}$ & Hrvatska & $33,51 \%$ & $37,50 \%$ & $27,93 \%$ & $0,80 \%$ & $0,27 \%$ & $\begin{array}{c}1,97 \\
(0,82)\end{array}$ \\
\cline { 2 - 7 } $\begin{array}{l}\text { u odnosu na pravosudne } \\
\text { sustave razvijenih zemalja } \\
\text { EU? }\end{array}$ & Srbija & $44,48 \%$ & $31,90 \%$ & $22,24 \%$ & $1,03 \%$ & $0,34 \%$ & $\begin{array}{c}1,81 \\
(0,84)\end{array}$ \\
\hline
\end{tabular}

1 = puno lošiji; 2 = nešto lošiji; 3 = ni bolji ni lošiji; 4 = nešto bolji; 5 = puno bolji

Da bismo jasnije razumjeli (ne)zadovoljstvo pravosudnim sustavom, ispitanicima smo postavili niz pitanja koja su mjerila zadovoljstvo pojedinim aspektima važnim za njegov rad i funkcioniranje (tablica 7 na sljedećoj stranici) ${ }^{17}$ Rezultati opet pokazuju da ispitanici u obje zemlje u prosjeku nisu zadovoljni nizom dimenzija pravosuđa. Svega u tri slučaja se vrijednosti aritmetičkih sredina nalaze iznad teorijskog prosjeka skale. Riječ je o procjeni stručnog znanja odvjetnika u obje zemlje i kvaliteti odvjetničkih usluga u Srbiji. Ipak, i u tim slučajevima aritmetičke sredine se nalaze bliže polju neutralnosti nego polju zadovoljstva.

Kao što smo i očekivali, faktorska analiza je pokazala da se u obje zemlje varijable grupiraju u tri faktora. ${ }^{18}$ Prvi faktor okuplja varijable koje se odnose na zadovoljstvo ispitanika postojećom organizacijom sudova, brzinom donošenja presuda, kvalitetom presuda i načinom na koji suci u svojem radu odolijevaju izvanjskim

${ }^{16}$ Ponovo je vidljivo da je jako mali broj ispitanika vrlo zadovoljan provedenim reformama. U Srbiji tek $0,35 \%$ ispitanika tvrdi da je njima vrlo zadovoljan, a u Hrvatskoj se tako nije izjasnio niti jedan ispitanik.

${ }^{17}$ Vrijednost Cronbachovog $\alpha$ koeficijenta instrumenta zadovoljstva funkcioniranjem dimenzija pravosudnog sustava u okviru hrvatskog uzorka iznosi 0,806, a u okviru srpskog uzorka 0,846 .

${ }^{18}$ U Hrvatskoj te dimenzije zajedno objašnjavaju 70,81\%, a u Srbiji 76,37\% ukupne varijance ovog instrumenta. 
Tablica 7. Distribucija zadovoljstva različitim aspektima funkcioniranja pravosudnog sustava

\begin{tabular}{|c|c|c|c|c|c|c|c|}
\hline $\begin{array}{l}\text { Koliko ste } \\
\text { zadovoljni: }\end{array}$ & Republika & 1 & 2 & 3 & 4 & 5 & M (SD) \\
\hline \multirow{2}{*}{$\begin{array}{l}\text { Primjerenošću } \\
\text { cijena odvjetničkih } \\
\text { usluga standardu } \\
\text { naših građana }\end{array}$} & Hrvatska & $23,98 \%$ & $30,25 \%$ & $31,34 \%$ & $12,53 \%$ & $1,91 \%$ & $2,38(1,04)$ \\
\hline & Srbija & $20,60 \%$ & $24,30 \%$ & $39,20 \%$ & $12,70 \%$ & $3,30 \%$ & $2,54(1,06)$ \\
\hline \multirow{2}{*}{$\begin{array}{l}\text { Kvalitetom usluga } \\
\text { koje pružaju } \\
\text { odvjetnici }\end{array}$} & Hrvatska & $7,01 \%$ & $20,49 \%$ & $47,44 \%$ & $23,72 \%$ & $1,35 \%$ & $2,92(0,88)$ \\
\hline & Srbija & $6,00 \%$ & $16,50 \%$ & $47,20 \%$ & $27,50 \%$ & $2,80 \%$ & $3,05(0,89)$ \\
\hline \multirow{2}{*}{$\begin{array}{l}\text { Stručnim znanjem } \\
\text { zakona i procedura } \\
\text { koje posjeduju } \\
\text { odvjetnici }\end{array}$} & Hrvatska & $3,53 \%$ & $20,11 \%$ & $47,55 \%$ & $27,45 \%$ & $1,36 \%$ & $3,03(0,82)$ \\
\hline & Srbija & $6,00 \%$ & $16,50 \%$ & $46,80 \%$ & $27,70 \%$ & $3,00 \%$ & $3,05(0,90)$ \\
\hline \multirow{2}{*}{$\begin{array}{l}\text { Postojećom } \\
\text { organizacijom } \\
\text { sudova } \\
\end{array}$} & Hrvatska & $16,35 \%$ & $30,56 \%$ & $34,05 \%$ & $18,23 \%$ & $0,80 \%$ & $2,57(0,99)$ \\
\hline & Srbija & $14,60 \%$ & $25,10 \%$ & $36,60 \%$ & $21,30 \%$ & $2,50 \%$ & $2,72(1,03)$ \\
\hline \multirow{2}{*}{$\begin{array}{l}\text { Kvalitetom presuda } \\
\text { koje donose sudovi }\end{array}$} & Hrvatska & $10,00 \%$ & $32,16 \%$ & $39,73 \%$ & $17,30 \%$ & $0,81 \%$ & $2,67(0,90)$ \\
\hline & Srbija & $13,40 \%$ & $30,70 \%$ & $38,10 \%$ & $15,70 \%$ & $2,10 \%$ & $2,62(0,97)$ \\
\hline \multirow{2}{*}{$\begin{array}{l}\text { Brzinom rješavanja } \\
\text { sporova / donošenja } \\
\text { presuda na našim } \\
\text { sudovima }\end{array}$} & Hrvatska & $30,73 \%$ & $43,67 \%$ & $17,25 \%$ & $7,55 \%$ & $0,81 \%$ & $2,04(0,92)$ \\
\hline & Srbija & $35,40 \%$ & $32,00 \%$ & $22,10 \%$ & $8,70 \%$ & $1,80 \%$ & $2,09(1,04)$ \\
\hline \multirow{2}{*}{$\begin{array}{l}\text { Načinom na koji } \\
\text { suci odolijevaju } \\
\text { izvanjskim } \\
\text { pritiscima }\end{array}$} & Hrvatska & $14,05 \%$ & $28,92 \%$ & $34,05 \%$ & $21,08 \%$ & $1,89 \%$ & $2,68(1,02)$ \\
\hline & Srbija & $24,30 \%$ & $31,20 \%$ & $30,30 \%$ & $11,40 \%$ & $2,80 \%$ & $2,37(1,06)$ \\
\hline \multirow{2}{*}{$\begin{array}{l}\text { Kvalitetom } \\
\text { optužnica koje } \\
\text { sastavljaju državni } \\
\text { odvjetnici }\end{array}$} & Hrvatska & $10,81 \%$ & $20,81 \%$ & $45,41 \%$ & $20,27 \%$ & $2,70 \%$ & $2,83(0,96)$ \\
\hline & Srbija & $18,40 \%$ & $27,60 \%$ & $41,50 \%$ & $11,70 \%$ & $0,90 \%$ & $2,49(0,95)$ \\
\hline \multirow{2}{*}{$\begin{array}{l}\text { Kvalitetom } \\
\text { rada državnog } \\
\text { odvjetništva }\end{array}$} & Hrvatska & $11,29 \%$ & $18,01 \%$ & $44,62 \%$ & $22,58 \%$ & $3,49 \%$ & $2,89(0,99)$ \\
\hline & Srbija & $18,00 \%$ & $29,10 \%$ & $39,90 \%$ & $11,80 \%$ & $1,20 \%$ & $2,49(0,96)$ \\
\hline \multirow{2}{*}{$\begin{array}{l}\text { Postojećom } \\
\text { organizacijom } \\
\text { državnog } \\
\text { odvjetništva }\end{array}$} & Hrvatska & $11,32 \%$ & $19,95 \%$ & $50,13 \%$ & $16,17 \%$ & $2,43 \%$ & $2,78(0,93)$ \\
\hline & Srbija & $15,70 \%$ & $25,70 \%$ & $46,70 \%$ & $10,40 \%$ & $1,40 \%$ & $2,56(0,92)$ \\
\hline
\end{tabular}

1 = uopće nisam zadovoljan; 2 = nisam zadovoljan; 3 = niti sam zadovoljan niti sam nezadovoljan; 4 = zadovoljan sam; $5=\mathrm{u}$ potpunosti sam zadovoljan 
pritiscima. Drugi faktor okuplja varijable koje se tiču zadovoljstva postojećom organizacijom državnog odvjetništva, kvalitetom njihovog rada općenito gledano te zadovoljstva kvalitetom optužnica koje sastavljaju. Konačno, treći faktor je grupirao varijable koje se odnose na zadovoljstvo ispitanika kvalitetom usluga koje pružaju odvjetnici, stručnim znanjem koje oni posjeduju i primjerenošću cijena odvjetničkih usluga standardu građana. ${ }^{19}$

Tablica 8. Analiza varijance - zadovoljstvo stanjem i funkcioniranjem pravosuđa prema profesiji

\begin{tabular}{|c|c|c|c|c|c|c|c|c|}
\hline Zadovoljstvo & $\begin{array}{l}\text { Repub- } \\
\text { lika }\end{array}$ & Suci & $\begin{array}{c}\text { Državni } \\
\text { odvjet- } \\
\text { nici }\end{array}$ & $\begin{array}{l}\text { Odvjet- } \\
\text { nici }\end{array}$ & $\begin{array}{c}\text { Pravni } \\
\text { znanstve- } \\
\text { nici }\end{array}$ & Ostali & $\mathbf{F}(\mathbf{p})$ & Post-hoc \\
\hline \multirow{2}{*}{$\begin{array}{l}\text { Općim } \\
\text { stanjem } \\
\text { u našem } \\
\text { pravosuđu }\end{array}$} & Hrvatska & $\begin{array}{c}2,54 \\
(0,87)\end{array}$ & $\begin{array}{c}2,25 \\
(0,91)\end{array}$ & $\begin{array}{c}1,96 \\
(0,79)\end{array}$ & $\begin{array}{c}2,35 \\
(0,77)\end{array}$ & $\begin{array}{c}2,03 \\
(0,72)\end{array}$ & $\begin{array}{l}7,147 \\
(0,00)\end{array}$ & $1>3$ i 5 \\
\hline & Srbija & $\begin{array}{c}2,52 \\
(0,88)\end{array}$ & $\begin{array}{c}2,60 \\
(0,96)\end{array}$ & $\begin{array}{c}1,86 \\
(0,73)\end{array}$ & $\begin{array}{c}2,07 \\
(0,70)\end{array}$ & $\begin{array}{c}2,16 \\
(0,90)\end{array}$ & $\begin{array}{c}19,078 \\
(0,00)\end{array}$ & $\begin{array}{c}1>3,4 \text { i } 5 \\
2>3 \text { i } 4\end{array}$ \\
\hline \multirow{2}{*}{$\begin{array}{l}\text { Reformama } \\
\text { koje su u } \\
\text { pravosuđu } \\
\text { provedene u } \\
\text { posljednjih } \\
20 \text { godina }\end{array}$} & Hrvatska & $\begin{array}{c}2,34 \\
(0,91)\end{array}$ & $\begin{array}{c}2,08 \\
(0,86)\end{array}$ & $\begin{array}{c}2,12 \\
(0,76)\end{array}$ & $\begin{array}{c}2,31 \\
(0,76)\end{array}$ & $\begin{array}{c}2,15 \\
(0,73)\end{array}$ & $\begin{array}{l}1,458 \\
(0,21)\end{array}$ & l \\
\hline & Srbija & $\begin{array}{c}2,21 \\
(0,91)\end{array}$ & $\begin{array}{c}2,27 \\
(0,96)\end{array}$ & $\begin{array}{c}1,91 \\
(0,82)\end{array}$ & $\begin{array}{c}2,00 \\
(0,78)\end{array}$ & $\begin{array}{c}2,22 \\
(0,90)\end{array}$ & $\begin{array}{l}4,375 \\
(0,00)\end{array}$ & $1>3$ \\
\hline \multirow{2}{*}{$\begin{array}{l}\text { Odvjetni- } \\
\text { štvom }\end{array}$} & Hrvatska & $\begin{array}{c}2,66 \\
(0,75)\end{array}$ & $\begin{array}{c}2,58 \\
(0,65)\end{array}$ & $\begin{array}{c}3,37 \\
(0,61)\end{array}$ & $\begin{array}{c}2,70 \\
(0,66)\end{array}$ & $\begin{array}{c}2,69 \\
(0,82)\end{array}$ & $\begin{array}{l}13,145 \\
(0,00)\end{array}$ & $3>1,2,4$ i 5 \\
\hline & Srbija & $\begin{array}{c}2,51 \\
(0,76)\end{array}$ & $\begin{array}{c}2,80 \\
(0,83)\end{array}$ & $\begin{array}{c}3,29 \\
(0,70)\end{array}$ & $\begin{array}{c}2,57 \\
(0,68)\end{array}$ & $\begin{array}{c}2,66 \\
(0,80)\end{array}$ & $\begin{array}{c}30,817 \\
(0,00)\end{array}$ & $3>1,2,4$ i 5 \\
\hline \multirow{2}{*}{$\begin{array}{l}\text { Državnim } \\
\text { odvjetni- } \\
\text { štvom }\end{array}$} & Hrvatska & $\begin{array}{c}2,86 \\
(0,74)\end{array}$ & $\begin{array}{c}3,53 \\
(0,76)\end{array}$ & $\begin{array}{c}2,44 \\
(0,93)\end{array}$ & $\begin{array}{c}2,75 \\
(0,62)\end{array}$ & $\begin{array}{c}2,62 \\
(0,78)\end{array}$ & $\begin{array}{c}20,516 \\
(0,00)\end{array}$ & $\begin{array}{c}1>3 \\
2>1,3,4 \text { i } 5\end{array}$ \\
\hline & Srbija & $\begin{array}{c}2,69 \\
(0,85)\end{array}$ & $\begin{array}{c}3,46 \\
(0,81)\end{array}$ & $\begin{array}{c}2,21 \\
(0,83)\end{array}$ & $\begin{array}{c}2,51 \\
(0,76)\end{array}$ & $\begin{array}{c}2,59 \\
(0,76)\end{array}$ & $\begin{array}{c}24,432 \\
(0,00)\end{array}$ & $\begin{array}{c}1>3 \\
2>1,3 \text { i } 5 \\
5>3\end{array}$ \\
\hline \multirow{2}{*}{ Sudstvom } & Hrvatska & $\begin{array}{c}2,98 \\
(0,65)\end{array}$ & $\begin{array}{c}2,58 \\
(0,69)\end{array}$ & $\begin{array}{c}2,20 \\
(0,68)\end{array}$ & $\begin{array}{c}2,43 \\
(0,60)\end{array}$ & $\begin{array}{c}2,25 \\
(0,68)\end{array}$ & $\begin{array}{l}18,745 \\
(0,00)\end{array}$ & $\begin{array}{c}1>2,3,4 \text { i } 5 \\
2>3 \text { i } 5\end{array}$ \\
\hline & Srbija & $\begin{array}{c}3,06 \\
(0,88)\end{array}$ & $\begin{array}{c}2,99 \\
(0,82)\end{array}$ & $\begin{array}{c}2,22 \\
(0,83)\end{array}$ & $\begin{array}{c}2,51 \\
(0,76)\end{array}$ & $\begin{array}{c}2,59 \\
(0,76)\end{array}$ & $\begin{array}{c}45,965 \\
(0,00)\end{array}$ & $\begin{array}{l}1>3,4 \text { i } 5 \\
2>3,4 \text { i } 5\end{array}$ \\
\hline
\end{tabular}

19 Pouzdanost subskale zadovoljstva funkcioniranjem sudstva u okviru hrvatskog uzorka iznosi 0,762, a u okviru srpskog 0,847. Pouzdanost subskale zadovoljstva funkcioniranjem državnog odvjetništva u okviru hrvatskog uzorka iznosi 0,876 , a u okviru srpskog 0,923. Pouzdanost subskale zadovoljstva funkcioniranjem odvjetništva u okviru hrvatskog uzorka iznosi 0,794, a u okviru srpskog 0,824 . 
Prvi važan nalaz analize varijance (tablica 8) je da u obje zemlje sve kategorije pravnika nisu zadovoljne ni općim stanjem u pravosuđu ni reformama koje su u njemu provedene. Smatramo da rezultati prikazani i u ovom odjeljku daju potporu pretpostavci o svojevrsnoj unutarnjoj krizi pravosuđa u našim zemljama. Ta unutarnja kriza izravno se iskazuje kroz visoku razinu nezadovoljstva pravnika općim stanjem u pravosuđu i važnim aspektima njegovog funkcioniranja.

Drugi nalaz je da su suci i tužitelji u Srbiji i suci u Hrvatskoj manje kritični prema stanju u pravosuđu od odvjetnika, pravnih znanstvenika i pravnika izvan pravosuđa. U Hrvatskoj su sve profesije podjednako nezadovoljne reformama i među njima ne postoje statistički značajne razlike. U Srbiji postoji razlika između sudaca (kao nešto manje nezadovoljnih) i odvjetnika (kao nešto više nezadovoljnih).

Treći nalaz je da je svaka profesija sklona gledati “svoj” (pod)sustav s manje kritičnosti. Primjerice, odvjetnici su u prosjeku zadovoljni stručnim znanjem i kvalitetom usluga koje pružaju, kao i primjerenošću cijena svojih usluga standardu građana, dok su ispitanici iz ostalih kategorija pravnika u prosjeku time nezadovoljni. Sličnu situaciju nalazimo i u slučaju zadovoljstva radom državnog odvjetništva: post-hoc testovi pokazuju da su u prosjeku u obje zemlje državni odvjetnici zadovoljniji radom državnog odvjetništva od sudaca, odvjetnika i ostalih pravnika koji ne rade u pravosuđu. Ipak, kada je riječ o sudovima, pripadnici svih profesija nezadovoljni su njihovim radom (aritmetičke sredine su ispod teorijskog prosjeka skale). Jedini izuzetak su srpski suci koji su u prosjeku neutralni ili tek blago zadovoljni stanjem u sudstvu. Konačno treba istaknuti da su odvjetnici generalno kritičniji prema različitim aspektima funkcioniranja pravosuđa. Primjerice, u obje zemlje oni su najnezadovoljniji radom državnog odvjetništva i sudstva. Pretpostavljamo da je to ponovo barem jednim dijelom posljedica njihove neovisne pozicije, ali i dovoljne uključenosti u sustav koja im daje blizak i dobro utemeljen uvid u njegovo funkcioniranje.

\section{7. Čimbenici institucionalnog (ne)povjerenja u pravosuđe: opća percepcija pravosuđa i zadovoljstvo funkcioniranjem njegovih posebnih aspekata}

U radu smo krenuli od pretpostavke da razina povjerenja u institucije ovisi o procjeni kvalitete njihovog rada te da je povjerenje u njih indikator unutarnjeg "zdravlja" sustava. Pretpostavku o vezi između povjerenja u pravosuđe i pravosudne institucije s jedne te zadovoljstva općim stanjem u pravosuđu i funkcioniranjem njegovih dijelova s druge strane testirali smo regresijskom analizom (tablica 9). U oba su modela kao kriterijske varijable korištene varijabla koja mjeri opće povjerenje u pravosuđe, skala povjerenja u "državne" i skala povjerenja u "nedržavne" pravosudne institucije. U prvom modelu su kao prediktori korištene varijable koje mjere opće 
zadovoljstvo stanjem u pravosuđu, zadovoljstvo reformama provedenim u posljednjih dvadeset godina i kvalitetu nacionalnog pravosuđa u odnosu na kvalitetu onih u razvijenim zemljama EU. U drugom modelu su kao prediktori korištene dobivene faktorske dimenzije u varimax rotaciji zadovoljstva bitnim aspektima rada sudstva, državnog odvjetništva i odvjetništva.

Tablica 9. Regresijska analiza značajnih prediktora povjerenja u pravosuđe i pravosudne institucije

\begin{tabular}{|c|c|c|c|c|}
\hline \multicolumn{5}{|c|}{ Model 1} \\
\hline \multicolumn{5}{|c|}{ Povjerenje u pravosuđe (općenito) } \\
\hline & \multicolumn{2}{|c|}{ Hrvatska } & \multicolumn{2}{|c|}{ Srbija } \\
\hline Zadovoljstvo: & Stand. $\beta$ & $p$ & Stand. $\beta$ & $p$ \\
\hline $\mathrm{u}$ odnosu na razvijene zemlje EU & 0,118 & 0,03 & 0,135 & 0,00 \\
\hline provedenim reformama & $-0,021$ & 0,70 & $-0,061$ & 0,19 \\
\hline općim stanjem u pravosuđu & 0,499 & 0,00 & 0,516 & 0,00 \\
\hline \multirow[t]{2}{*}{ Adjusted $R^{2}$} & \multicolumn{2}{|c|}{0,309} & \multicolumn{2}{|c|}{0,306} \\
\hline & \multicolumn{2}{|l|}{$F=54,457$} & $F=79,115$ & $p<0,00$ \\
\hline \multicolumn{5}{|c|}{ Skala povjerenja u “državne” pravosudne institucije } \\
\hline & \multicolumn{2}{|c|}{ Hrvatska } & \multicolumn{2}{|c|}{ Srbija } \\
\hline Zadovoljstvo: & Stand. $\beta$ & $p$ & Stand. $\beta$ & $p$ \\
\hline u odnosu na razvijene zemlje EU & 0,017 & 0,76 & 0,079 & 0,05 \\
\hline provedenim reformama & 0,065 & 0,25 & 0,079 & 0,08 \\
\hline općim stanjem u pravosuđu & 0,480 & 0,00 & 0,480 & 0,00 \\
\hline \multirow[t]{2}{*}{ Adjusted $R^{2}$} & \multicolumn{2}{|c|}{0,260} & \multicolumn{2}{|c|}{0,330} \\
\hline & $F=44,504$ & $p<0,00$ & $F=94,437$ & $p<0,00$ \\
\hline \multicolumn{5}{|c|}{ Skala povjerenja u "nedržavne" pravosudne institucije } \\
\hline & \multicolumn{2}{|c|}{ Hrvatska } & \multicolumn{2}{|c|}{ Srbija } \\
\hline Zadovoljstvo: & Stand. $\beta$ & $p$ & Stand. $\beta$ & $p$ \\
\hline u odnosu na razvijene zemlje EU & 0,050 & 0,40 & $-0,033$ & 0,48 \\
\hline provedenim reformama & 0,090 & 0,14 & $-0,078$ & 0,13 \\
\hline općim stanjem u pravosuđu & 0,278 & 0,00 & 0,379 & 0,00 \\
\hline \multirow[t]{2}{*}{ Adjusted $R^{2}$} & \multicolumn{2}{|c|}{0,130} & \multicolumn{2}{|c|}{0,099} \\
\hline & $F=19,501$ & $p<0,00$ & $F=21,736$ & $p<0,00$ \\
\hline
\end{tabular}




\begin{tabular}{|c|c|c|c|c|}
\hline \multicolumn{5}{|c|}{ Model 2} \\
\hline \multicolumn{5}{|c|}{ Povjerenje u pravosuđe (općenito) } \\
\hline & \multicolumn{2}{|c|}{ Hrvatska } & \multicolumn{2}{|c|}{ Srbija } \\
\hline Zadovoljstvo: & Stand. $\beta$ & $p$ & Stand. $\beta$ & $p$ \\
\hline Državnim odvjetništvom & 0,402 & 0,00 & 0,265 & 0,00 \\
\hline Sudstvom & 0,599 & 0,00 & 0,573 & 0,00 \\
\hline Odvjetništvom & 0,119 & 0,00 & $-0,028$ & 0,43 \\
\hline \multirow[t]{2}{*}{ Adjusted $R^{2}$} & \multicolumn{2}{|c|}{0,485} & \multicolumn{2}{|c|}{0,393} \\
\hline & $F=102,517$ & $p<0,00$ & $F=104,743$ & $p<0,00$ \\
\hline \multicolumn{5}{|c|}{ Skala povjerenja u "državne" pravosudne institucije } \\
\hline & \multicolumn{2}{|c|}{ Hrvatska } & \multicolumn{2}{|c|}{ Srbija } \\
\hline Zadovoljstvo: & Stand. $\beta$ & $p$ & Stand. $\beta$ & $p$ \\
\hline Državnim odvjetništvom & 0,497 & 0,00 & 0,452 & 0,00 \\
\hline Sudstvom & 0,476 & 0,00 & 0,536 & 0,00 \\
\hline Odvjetništvom & 0,243 & 0,00 & 0,088 & 0,00 \\
\hline Adjusted $R^{2}$ & \multicolumn{2}{|c|}{0,529} & \multicolumn{2}{|c|}{0,499} \\
\hline & $F=127,433$ & $p<0,00$ & $F=169,900$ & $p<0,00$ \\
\hline \multicolumn{5}{|c|}{ Skala povjerenja u "nedržavne" pravosudne institucije } \\
\hline & \multicolumn{2}{|c|}{ Hrvatska } & \multicolumn{2}{|c|}{ Srbija } \\
\hline Zadovoljstvo: & Stand. $\beta$ & $p$ & Stand. $\beta$ & $p$ \\
\hline Državnim odvjetništvom & 0,185 & 0,00 & 0,187 & 0,00 \\
\hline Sudstvom & 0,332 & 0,00 & 0,362 & 0,00 \\
\hline Odvjetništvom & 0,471 & 0,00 & \begin{tabular}{l|l}
0,299 & \\
\end{tabular} & 0,00 \\
\hline Adjusted $R^{2}$ & \multicolumn{2}{|c|}{0,361} & \multicolumn{2}{|c|}{$\begin{array}{ll}R^{2} & 0,251 \\
\end{array}$} \\
\hline & $F=64,603$ & $p<0,00$ & $F=58,424$ & $p<0,00$ \\
\hline
\end{tabular}

Pokazalo se da rezultati regresijskih analiza daju potvrdu općoj hipotezi rada i drugoj posebnoj hipotezi, ali i da istovremeno samo djelomično potvrđuju neke elemente prve posebne hipoteze. $U$ obje zemlje postoji povezanost između razine povjerenja u pravosuđe i institucije pravosudnog sustava i zadovoljstva općim stanjem u pravosuđu (model 1) i njegovim zasebnim elementima (model 2). Neočekivano, zadovoljstvo provedenim reformama se nije pokazalo kao statistički značajan prediktor ni u jednoj zemlji. Taj podatak je utoliko čudniji ako se imaju u vidu kontroverze koje je rasprava o reformama pravosuđa izazvala u obje zemlje, a posebno 
u Srbiji. No, čini se da postoji temeljna pretpostavka o nezadovoljavajućem funkcioniranju pravosuđa i da je ona jača od stavova o provedenim reformama pravosuđa.

U prvom modelu pokazuje se da što je veće zadovoljstvo općim stanjem u pravosuđu, to je veće i povjerenje u pravosuđe generalno gledano i povjerenje u "državne" pravosudne institucije. Ta je veza kod "nedržavnih" institucija pravosuđa također značajna, ali je nešto slabija. Pored toga, treba naglasiti da se u prvom modelu pokazalo da zadovoljstvo općim stanjem u pravosuđu ima bitno bolje prediktivne karakteristike u određivanju razine povjerenja u pravosuđe općenito gledano od usporedbe s EU. Rezultati drugog modela pokazuju da ispitanici koji su zadovoljniji funkcioniranjem sudstva, državnog odvjetništva i odvjetništva u obje zemlje pokazuju u relativnom smislu i veće povjerenje u pravosuđe generalno gledano i veće povjerenje u "državne" i "nedržavne" pravosudne institucije. Sve tri varijable pokazuju se kao statistički značajni prediktori. Jedini izuzetak nalazimo u Srbiji u slučaju kada je kriterijska varijabla povjerenje u pravosuđe općenito gledano. Uz to treba naglasiti da prediktorske varijable tog modela tumače nešto veći postotak varijance kriterijskih varijabli nego prediktori korišteni u prvom modelu. Da zaključimo, dobiveni rezultati iz oba modela jasno pokazuju da je (ne)povjerenje u pravosudni sustav i njegove institucije izravno povezano s (ne)zadovoljstvom njihovim radom. Ti nalazi potvrđuju tezu da se povjerenje u institucije može objašnjavati kao posljedica evaluacije učinaka njihovog rada.

\section{Zaključna razmatranja}

Iako se povjerenje građana u pravosuđe redovno provjerava istraživanjem javnog mnijenja i znanstvenim istraživanjima, samo povjerenje pripadnika pravničkih profesija u pravosuđe u pravilu nije poseban predmet ovakvih istraživanja. Smatrali smo da je to posebno važno, jer ako se povjerenje promatra u kontekstu nekog institucionalnog sustava i onih aktera koji u njemu rade ili su kroz svoj rad s njim povezani, ono je važan pokazatelj unutarnjeg legitimiteta i "dobrog” funkcioniranja tog sustava. Iz tog smo razloga, ali i zbog toga što je stanje u pravosuđu u Hrvatskoj i Srbiji predmet stalnih polemika i brojnih kritika, odlučili istražiti koliko povjerenja pravnici u našim zemljama imaju u institucije pravosuđa i koliko su zadovoljni njegovim radom.

Krenuli smo od pretpostavke da pravosuđe treba posjedovati određene karakteristike kako bi se u nekom društvu uspostavila demokratska vladavina prava. U tom kontekstu pravosuđe mora biti de iure i de facto nezavisno od drugih grana vlasti, mora imati stručne kapacitete i aktere koji su sposobni tumačiti zakone i donositi argumentirane odluke te mora biti efikasno, $\mathrm{tj}$. sposobno donositi odluke u razumnom roku, bez nepotrebnog odlaganja. Zbog toga smo upravo u okviru tih dimen- 
zija analizirali zadovoljstvo pravnika funkcioniranjem važnih dijelova pravosuđa. Naravno, pravosuđe smo promatrali u specifičnom društveno-političkom kontekstu naše dvije zemlje. U Hrvatskoj je taj kontekst obilježen formalno provedenim reformama koje su makar načelno stvorile pretpostavke da pravosuđe bude nezavisno od političke vlasti, sposobno štititi zakonitost i interese svih građana te sposobno procesuirati vršioce vlasti u slučaju zlouporaba. Nasuprot tome, kontekst razvoja srpskog pravosuđa uglavnom je obilježen stanjem višegodišnjih neuspješnih reformi, jakim utjecajem izvršne vlasti te manjom razinom formalnih i praktičnih sposobnosti da se kontrolira korupcija i zlouporaba javnih resursa. U tom smislu se generalno gledano može primijetiti nešto veći skepticizam i distanciranost anketiranih srpskih pravnika prema institucijama državno-političkog sustava, pravosudno-represivnog sustava i građanskog društva od njihovih hrvatskih kolega. Ipak, bez obzira na te razlike pokazuje se da anketirani pravnici u obje zemlje u prosjeku zaključuju da provedene reforme nisu dovele pravosudne sustave na zadovoljavajuću razinu približnu razvijenim zemljama EU, te su većinom nezadovoljni stanjem u njemu.

Shodno tome, smatramo da podaci dobiveni u obje zemlje ukazuju na svojevrsnu unutarnju krizu pravosuđa (krizu unutarnjeg legitimiteta) koja se ogleda u niskoj razini povjerenja u pravosuđe i njegove institucije te u nezadovoljstvu funkcioniranjem njegovih važnih dijelova. Rezultati su također pokazali da različite pravničke profesije nemaju jednaku razinu povjerenja u institucije pravosuđa te da nisu podjednako nezadovoljne radom njegovih važnih dijelova. Ispada da je to makar dijelom povezano sa stupnjem socioekonomske i profesionalne (ne)zavisnosti aktera u odnosu na pravosudni sustav. Suci i državni odvjetnici, koji su u tom smislu snažnije povezani sa sustavom, imaju nešto više povjerenja u njegove institucije te su nešto manje od ostalih profesija nezadovoljni funkcioniranjem njegovih važnih dijelova. Nasuprot tome, odvjetnici, pravni znanstvenici i pravnici izvan pravosuđa, dakle oni akteri koji pokazuju veći stupanj profesionalne i socioekonomske neovisnosti u odnosu na sustav, iskazuju prema njemu nešto veće nepovjerenje i nezadovoljstvo od sudaca i državnih odvjetnika. Konačno, rezultati su potvrdili i to da postoji jasna povezanost između povjerenja u pravosuđe i pravosudne institucije i zadovoljstva općim stanjem u pravosuđu i funkcioniranjem njegovih važnih dijelova. Što je veće zadovoljstvo općim stanjem u pravosuđu, to je veće i povjerenje u pravosudni sustav i njegove institucije. Jednako tako, što je veće zadovoljstvo ispitanika funkcioniranjem sudstva, državnog odvjetništva i odvjetništva, to je veće i povjerenje u pravosuđe općenito gledano i povjerenje u "državne" i "nedržavne" pravosudne institucije.

Budući da su prikazani rezultati dobiveni na prigodnom, a ne reprezentativnom uzorku pripadnika pravničkih profesija u našim zemljama, navedenu problematiku će trebati dodatno istražiti, a dobivene rezultate verificirati u nekim budućim istra- 
živanjima. Ipak, rezultati koje smo dobili u ovom istraživanju pokazuju da se naši pravosudni sustavi susreću s brojnim problemima i izazovima koji ometaju njihovu funkcionalnost i "dobar" rad u kontekstu nastojanja da se uspostavi demokratska vladavina prava u našim društvima.

\section{LITERATURA}

Baloban, Stjepan i Ivan Rimac. 1998. Povjerenje u institucije u Hrvatskoj. Bogoslovska smotra, (68), 4: 663-672.

Bešić, Miloš. 2016. Confidence in Institutions in Former Yugoslav Republics. Sociologija, (53), 2: 302-318.

Bühlmann, Marc i Ruth Kunz. 2011. Confidence in the Judiciary: Comparing the Independence and Legitimacy of Judicial Systems. West European Politics, (34), 2: 317-345.

CEPRIS. 2016. Ustavni položaj pravosuđa - Analiza i preporuke za izmene. Beograd: CEPRIS i OEBS, dostupno na: http://www.cepris.org/wp-content/uploads/2017/02/ CEPRIS.Ustavni-polo\%C5\%BEaj-sudske-vlasti.PROJEKAT.OEBS_.decembar-2016.pdf

Cerruti, Tanja. 2014. The Political Criteria for Accession to the EU in the Experience of Croatia. European Public Law, (20), 4: 771-798.

CESID. 2017. Javno mnenje Srbije. Politički aktivizam građana Srbije. Cesid. Beograd.

Chemerinsky, Erwin. 2001. Bush v. Gore Was Not Justiciable. Notre Dame Law Review, (76), 4: 1093-1112.

Coman, Ramona. 2014. Quo vadis judicial reforms? The quest for judicial independence in Central and Eastern Europe. Europe-Asia Studies, (66), 6: 892-924.

Cvejić, Slobodan (ur.). 2016. Informal Power Networks, Political Patronage and Clientelism in Serbia and Kosovo*. SeConS. Beograd.

Dallara, Cristina. 2014. Democracy and Judicial Reforms in South-East Europe: Between the EU and the Legacies of the Past. Springer. Cham.

De Vos, Pierre i Jaco Barnard. 2007, Same-sex marriage, civil unions and domestic partnerships in South Africa, critical reflections on an ongoing saga. South African Law Journal, (124), 4: 795-826.

EC. 2010. Serbia 2010 Report. Com (2010), 660.

EC. 2012. Serbia 2012 Report. Com (2012), 600 final.

EC. 2014. Serbia 2014 Report. Com (2014), 700 final.

EC. 2016. Serbia 2016 Report. Com (2016), 715 final.

EC. 2018. Serbia 2018 Report. Com (2018), 450 final. 
Elbasani, Arolda i Senada Šelo Šabić. 2018. Rule of law, corruption and democratic accountability in the course of EU enlargement. Journal of European Public Policy, (25), 9: 1317-1335.

Fallon Jr, Richard H. 2005. Legitimacy and the Constitution. Harvard Law Review, (118), 6: 1787-1853.

Freitag, Marcus i Marc Bühlmann. 2009. Crafting Trust. The Role of Political Institutions in a Comparative Perspective. Comparative Political Studies, (42) 12: 15371566.

Gibson, James L., Gregory A. Caldeira i Lester Kenyatta Spence. 2003. The Supreme Court and the US Presidential Election of 2000: Wounds, Self-Inflicted or Otherwise?. British Journal of Political Science, (33), 4: 535-556.

Gvozdanović, Anja. 2014. Politički utjecaj i vrijednosti kao odrednice političkog povjerenja mladih u Hrvatskoj. Revija za sociologiju, (44), 1: 5-30.

Hetherington, Marc. 1998. The political relevance of political trust. American Political Science Review, (92), 4: 791-808.

HS. 2010. Strategija reforme pravosuđa, za razdoblje od 2011. do 2015. godine, Hrvatski Sabor, dostupno na: https://pravosudje.gov.hr/UserDocsImages//dokumenti//Strategija\%20reforme\%20pravosu\%C4\%91a,\%20za\%20razdoblje\%20od\%202011.\%20 do\%202015..pdf, 27. 11. 2018.

HS. 2012. Strategija razvoja pravosuđa, za razdoblje od 2014. do 2018. godine, Hrvatski Sabor, dostupno na: https://pravosudje.gov.hr/UserDocsImages/dokumenti/Strategija\%20razvoja\%20pravosuđa,\%20za\%20razdoblje\%20od\%202013.\%20do\%20 2018..pdf, 27. 11. 2018.

Ilić, Goran. 2018. Kritičko razmatranje Radnog teksta amandmana Ministarstva pravde na Ustav Republike Srbije (stranputice u tumačenju međunarodnih dokumenata), Fondacija Centar za javno pravo, dostupno na: http://www.fcjp.ba/index.php/projekti

Inglehart, Roland. 1997. Modernization and Postmodernization. Cultural, Economic and Political Change in 43 Societies. Princeton University Press. Princeton.

IPSOS. 2016. Izvješće evaluacije kvalitete usluga pravosudnog sustava u Republici Hrvatskoj 2016. Ministarstvo pravosuđa, dostupno na https://pravosudje.gov.hr/vijesti/ istrazivanje-u-sklopu-projekta-potpore-pravosudnom-sustavu/14737

Jerinić, Jelena i Tijana Kljajević. 2016. Analiza stručnih i političkih predloga za ustavnu reformu. U javnosti predstavljeni predlozi u periodu 2006-2016. Fondacija Fridrih Ebert, Beograd, dostupno na: http://library.fes.de/pdf-files/bueros/belgrad/12950.pdf

Levi, Margaret i Laura Stoker. 2000. Political trust and trustworthiness. Annual Review of Political Science, (3), 1: 475-507.

Maldini, Pero. 2008. Političko povjerenje i demokratska konsolidacija. Politička misao, (45), 1: 179-199. 
Marinković, Tanasije. 2009. O ustavnosti opšteg reizbora sudija. Anali Pravnog fakulteta u Beogradu, (57), 1: 283-291.

Marković, Ratko. 2010. Sudstvo - Ahilova peta države Srbije, Pečat, dostupno na: http:// www.pecat.co.rs/2010/04/sudstvo-ahilova-peta-drzave-srbije/, 28. 4. 2010.

Matić, Davorka. 2000. Demokracija, povjerenje i socijalna pravda. Revija za sociologiju, (31), 3-4: 183-195.

Mendelski, Martin. 2015. The EU's Pathological Power: The Failure of External Rule of Law Promotion in South Eastern Europe. Southeastern Europe, (39), 3: 318-346.

Mishler, William i Richard Rose. 2001. What are the origins of political trust? Testing institutional and cultural theories in post-communist societies. Comparative political studies, (34), 1: 30-62.

Mishler, William i Richard Rose. 2005. What are the political consequences of trust? A test of cultural and institutional theories in Russia. Comparative Political Studies, (38), 9: 1050-1078.

MPV. 2014. Funkcionalna analiza pravosuđa u Srbiji. Izveštaj br. 94014-YF. Multidonorski poverenički fond za podršku sektoru pravosuđa u Srbiji. Beograd.

Mrakovčić, Marko. 2010. (Dez)integracija i povjerenje u institucije u višeetničkim zajednicama Hrvatske. Revija za sociologiju, (40), 2: 157-184.

Newton, Keneth i Pippa Norris. 1999. Confidence in Public Institutions: Faith, Culture or Performance?, izlaganje na godišnjoj konferenciji American Political Science Association, Atlanta, 1-5. rujna 1999.

Noutcheva, Gergana i Senem Aydin-Düzgit. 2012. Lost in Europeanisation: The Western Balkans and Turkey. West European Politics, (35), 1: 59-78.

Orlović, Slobodan. 2010. Stalnost sudijske funkcije vs. Opšti reizbor sudija u Republici Srbiji. Anali Pravnog fakulteta u Beogradu, (58), 2: 163-196.

Pavlović, Dejan. 2010. Reforma pravosuđa u Srbiji posle 5. oktobra, u: Dušan Pavlović (ur.): Razvoj demokratskih ustanova u Srbiji - deset godina posle. Fondacija Heinrich Böll. Beograd: 83-94.

Petrović Škero, Vida. 2018. Nacrt amandmana na ustavne odredbe o pravosuđu i mišljenje Venecijanske komisije br. 921/2018 o Nacrtu amandmana. Fondacija Centar za javno pravo, dostupno na: http://www.fcjp.ba/index.php/projekti

R.D. 2018. "Progon sudije koja je odbila da sudi prema sugestijama". Danas, 6. studenog 2018. godine, dostupno na https://www.danas.rs/politika/progon-sudije-kojaje-odbila-da-sudi-prema-sugestijama/

Rakić-Vodinelić, Vesna. 2010. Kojim putem ka vladavini zakona, Republika, br. 476/477.

Rakić-Vodinelić, Vesna, Ana Knežević Bojović i Mario Reljanović. 2012. Reforma pravosuđa u Srbiji 2008-2012. Pravni fakultet Univerziteta Union u Beogradu. Beograd, JP Službeni glasnik. 
Rodin, Siniša. 2011. Pravo Europske unije i pravni poredak Republike Hrvatske nakon 20 godina hrvatskog Ustava, u: Bačić, Arsen (ur.): Dvadeseta obljetnica Ustava Republike Hrvatske. HAZU. Zagreb: 87-118.

Roux, Theunis. 2009. Principle and pragmatism on the Constitutional Court of South Africa. Icon-International Journal of Constitutional Law, (7), 1: 106-138.

Sekulić, Duško i Željka Šporer. 2010. Gubimo li povjerenje u institucije?, u: Josip Kregar, Duško Sekulić i Željka Šporer (ur.): Korupcija i povjerenje. Centar za demokraciju i pravo Miko Tripalo i Pravni fakultet Sveučilišta u Zagrebu. Zagreb: 71-117.

Shultz, Ulrike i Gisela Shaw. 2003. Women in the World's Legal Professions. Hart Publishing. Oxford - Portland.

Sibinović, Đorđe. 2011. Pravo advokature. Službeni glasnik. Beograd.

Spasić, Slobodan, Nebojša Šarkić i Đorđe Sibinović. 2011. Pravosudne profesije. Službeni glasnik. Beograd.

Stanojević, Dragan, Marija Babović i Dragana Gundogan. 2016. Actors, Resources and Mechanisms of Clientelism in Serbia, u: Cvejić, Slobodan (ur.): Informal Power Networks, Political Patronage and Clientelism in Serbia and Kosovo*. SeConS. Beograd: 44-65.

Tamanaha, Brian Z. 2004. On the Rule of Law. History, Politics, Theory. University Press. Cambridge.

Uzelac, Alan. 2013. Croatia, u: van Rhee, C. H. (Remco) i Yulin, Fu (ur.): Civil Litigation in China and Europe: Essays on the Role of the Judge and the Parties. Springer. Dordrecht: 197-223.

Vuković, Danilo. 2018. The Quest for Government Accountability and Rule of Law: Conflicting Strategies of State and Civil Society in Cambodia and Serbia. Voluntas: International Journal of Voluntary and Nonprofit Organizations, (29), 3: 590-602.

Vuković, Danilo i Slobodan Cvejić. 2014. Legal culture in contemporary Serbia: Structural analysis of attitudes towards the rule of law. Annals of the Faculty of Law in Belgrade, (62), 3: 52-73.

Vuković, Danilo i Slobodan Cvejić. 2019. Attitudes Towards the Rule of Law in Contemporary Serbia: A Coherent Legal Culture? Jahrbuch für Ostrecht (prihvaćen za objavljivanje).

Vuković, Danilo, Valerija Dabetić i Samir Forić. 2019. Serbia and Bosnia and Herzegovina, u: Abel, Richard et al. (ur.): Lawyers in Society - 30 Years Later. Hart Publishing. Oxford (prihvaćen za objavljivanje).

Vuković, Danilo, Marko Mrakovčić i Samir Forić. 2018. Legal Professions in South East Europe: From Post-Socialist Transformation to Globalization, izlaganje na godišnjoj konferenciji CSL i SDJ u Lisabonu, The Law and Citizenship Beyond the State, 10-13 rujna 2018. 


\title{
Marko Mrakovčić, Danilo Vuković \\ "INTERNAL" CRISIS OF JUDICIARY? \\ ATTITUDES OF MEMBERS OF THE LEGAL PROFESSIONS \\ IN CROATIA AND SERBIA TOWARDS JUDICIARIES \\ IN THEIR COUNTRIES
}

\begin{abstract}
Summary
In this paper we analyze attitudes of members of the legal professions in Croatia and Serbia with regards to the judicial systems - the trust in judicial institutions and satisfaction with their performance. In the first part of the paper we present arguments of the cultural and institutional approach to explaining the foundations of trust in institutions, then define the characteristics of a "good" judiciary in the context of the democratic rule of law, and present the socio-political context of judicial reform in both countries over the last twenty years. In the second, empirical part of the paper we analyze the data collected through the online survey conducted among members of the legal professions in 2018 in Croatia and Serbia. The results from both countries show a low level of trust in judiciary and deep dissatisfaction with the functioning of judiciary on a list of dimensions. Our analysis confirms the link between (dis)trust in institutions and (dis)satisfaction with their work and thus also the assumptions of the institutional perspective on trust. We conclude that the obtained results point to an "internal" crisis of trust in judiciary in both countries, which accompanies the evident "external" crisis of the Serbian judiciary and the latent tensions in and around the Croatian judiciary.
\end{abstract}

Keywords: Judiciary, Crisis, Legitimacy, Trust in Institutions, Legal Professions, Croatia, Serbia

Marko Mrakovčić je docent na Katedri za sociologiju Pravnog fakulteta Sveučilišta u Rijeci.

Danilo Vuković je izvanredni profesor na Katedri za teoriju, sociologiju i filozofiju prava Pravnog fakulteta Univerziteta u Beogradu.

Kontakti:

Marko Mrakovčić, Pravni fakultet Sveučilišta u Rijeci, Hahlić 6, 51000 Rijeka. E-mail:mmrakovcic@pravri.hr

Danilo Vuković, Pravni fakultet, Univerzitet u Beogradu, Bulevar kralja Aleksandra 67, 11000 Beograd, Srbija. E-mail: danilo.vukovic@ius.bg.ac.rs 